Portland State University

PDXScholar

11-8-1996

\title{
A Preliminary Comparison of Two ESL School Models for Newcomer Students
}

Elizabeth Carol Essex

Portland State University

Follow this and additional works at: https://pdxscholar.library.pdx.edu/open_access_etds

Part of the Bilingual, Multilingual, and Multicultural Education Commons Let us know how access to this document benefits you.

\section{Recommended Citation}

Essex, Elizabeth Carol, "A Preliminary Comparison of Two ESL School Models for Newcomer Students" (1996). Dissertations and Theses. Paper 5075.

https://doi.org/10.15760/etd.6949

This Thesis is brought to you for free and open access. It has been accepted for inclusion in Dissertations and Theses by an authorized administrator of PDXScholar. Please contact us if we can make this document more accessible: pdxscholar@pdx.edu. 


\section{THESIS APPROVAL}

The abstract and thesis of Elizabeth Carol Essex for the Master of Arts in TESOL were presented November 8,1996 , and accepted by the thesis committee and the department.

COMMITTEE APPROVALS:

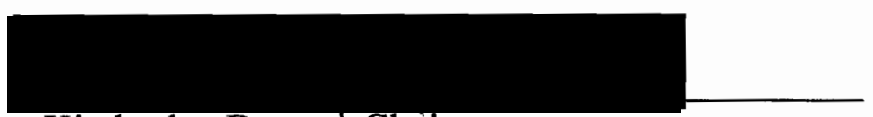

Kimberley Brown Chair
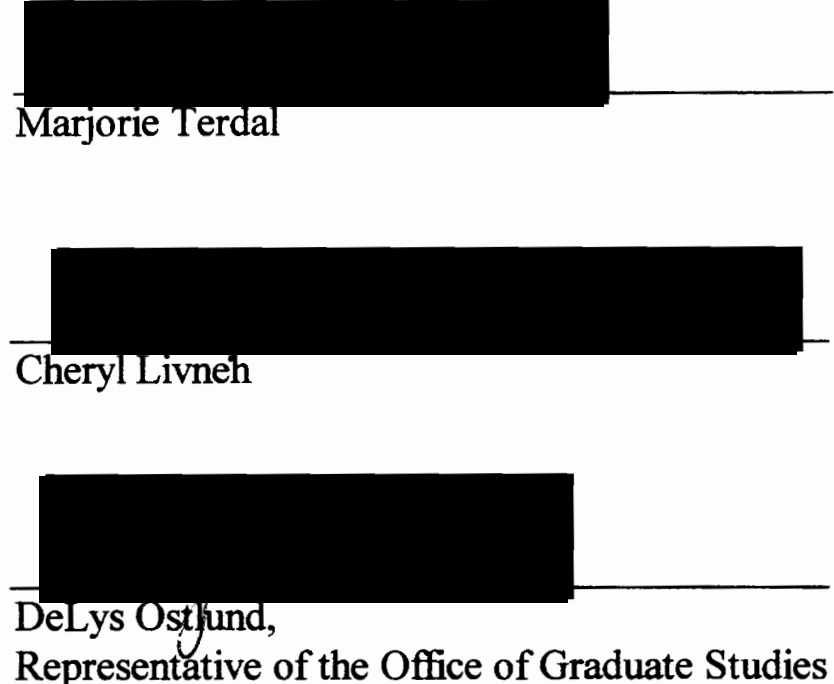

DEPARTMENT APPROVAL:

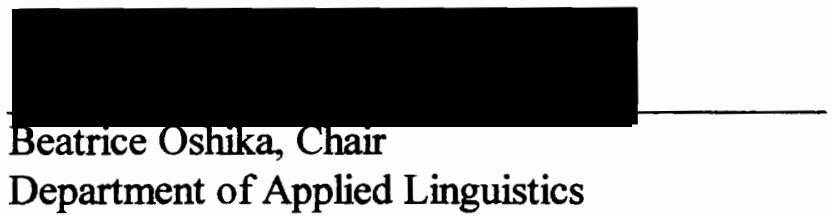

$* * * * * * * * * * * * * * * * * * * * * * * * * * * * * * * * * * * * * * * * * * * * * * * * * * * * * * * * * * * * * * * * * * * * * *$

\section{ACCEPTED FOR PORTLAND STATE UNIVERSITY BY THE LIBRARY}

by

on

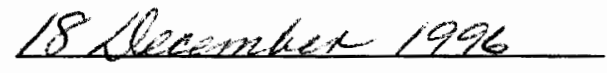




\begin{abstract}
An abstract of the thesis of Elizabeth Carol Essex for the Master of Arts in TESOL presented November 8, 1996.
\end{abstract}

Title: A Preliminary Comparison of Two ESL School Models for Newcomer Students.

Due to the ever growing numbers of immigrants entering this country, school districts are faced with ever greater challenges for educating newly arrived immigrant students. Often these students arrive with little to no English ability and little to no school experience. Several educational program models, including ESL and bilingual education, have been popularized in school districts experiencing immigrant population growth.

Recently, a supplemental model, the newcomer center/program, has gained popularity. The newcomer model seeks to educate and nurture newly arrived immigrant students with little to no English ability in the social and school expectations of the United States.

Due to difficulties in conducting research and the relative newness of the program, there is a lack of quantitative research on the effectiveness of the newcomer model. The purpose of this study was to examine the effectiveness of the newcomer program in one city school district by comparing students who had completed the newcomer program to students who had been unable to attend and were instead directly mainstreamed into their regular assigned schools. 
The study used a questionnaire design in which the mainstream teachers were asked to rate the students using a Likert scale. Students were rated on their social and school adjustment. In addition to comparing students by program model group (newcomer and pre-beginner), statistical analyses were also used to determine any possible differences among gender, language groups and student ages.

Although no significant difference was found between the group of students who successfully completed the newcomer program and the group of students who were directly mainstreamed, there were a few significant findings among gender, age and language comparisons. 


\section{A PRELIMINARY COMPARISON OF TWO \\ ESL SCHOOL MODELS FOR NEWCOMER STUDENTS}

by

ELIZABETH CAROL ESSEX

A thesis submitted in partial fulfillment of the requirements for the degree of

\section{MASTER OF ARTS \\ in \\ TESOL}

Portland State University

1996 


\section{ACKNOWLEDGEMENTS}

As with most worthwhile things in life, this Master's degree and thesis have been a long time in the making. During this time, many people have supported and encouraged me along the way. First, there is the "Family of Beth." I am blessed with a large, loving, extended family made up of not only the usual mother and father, but stepparents, brothers and sisters, uncles and aunts, grandparents, cousins and the "J5". In addition I would like to thank Heidi, Karen, Susan, Patty, Sharon, Allen, Rebecca and Jason. These friends have put up with my day to day struggles with patience and plenty of fun. I would also like to thank Tou Meksavanh, Mary Fulton, Heidi Maxfield, Joanne Hodgdon and Marty McCall of the ESL/Bilingual Department of the Portland Public School System for answering my many questions and allowing me access to program lists and test results in order to carry out my research. I greatly appreciate the many dedicated teachers of the Portland district who took the time to answer the questionnaire and talk to me about their students. I am indebted to Sally Anderson, Christine O'Donovan, Susan Lawrence and Margot Faegre of the elementary newcomer center for giving me the opportunity to work with and learn from such wonderful teachers as themselves.

I would like to extend a special thanks to the Applied Linguistics department, especially Kim Brown. Kim patiently supported me throughout my four years in the department and her faith in my ability remained strong until the end. Merci beaucoup.

Finally, I would like to thank Heath for getting me into this project in the first place, and Paul for getting me through the final stages and on to the rest of my life. 
PAGE

ACKNOWLEDGMENTS $\ldots \ldots \ldots \ldots \ldots \ldots \ldots \ldots \ldots \ldots \ldots$ ii

LIST OF TABLES $\ldots \ldots \ldots \ldots \ldots \ldots \ldots \ldots \ldots \ldots \ldots \ldots \ldots \ldots \ldots \ldots \ldots \ldots$

LIST OF FIGURES $\ldots \ldots \ldots \ldots \ldots \ldots \ldots \ldots \ldots \ldots \ldots \ldots \ldots \ldots \ldots$ vii CHAPTER

I INTRODUCTION AND STATEMENT OF PURPOSE ..... 1

Introduction $\ldots \ldots \ldots \ldots \ldots \ldots \ldots \ldots \ldots \ldots, 1$

Statement of Purpose $\ldots \ldots \ldots \ldots \ldots \ldots \ldots \ldots, 5$

Definition of Terms $\ldots \ldots \ldots \ldots \ldots \ldots \ldots \ldots, 8$

II REVIEW OF THE LITERATURE $\ldots \ldots \ldots \ldots \ldots \ldots \ldots . .11$

Historical Overview of Immigration ........... 11

Historical Overview of Immigrant Education . . . . . 22

Lau vs. Nichols $\ldots \ldots \ldots \ldots \ldots \ldots \ldots \ldots, 27$

Second Language Acquisition Research ......... 27

Cultural Identity and Acculturation ........ 29

Program Models $\ldots \ldots \ldots \ldots \ldots \ldots \ldots \ldots \ldots \ldots, 32$

Description of a Newcomer Program .......... 36

Intake Criteria .................. 36

Program Model .................. 36

Curriculum .................... 37

Exit Criteria $\ldots \ldots \ldots \ldots \ldots \ldots \ldots \ldots . \ldots \ldots$ 
Portland Public School System . . . . . . . . . . 38

Assessment ....................... 39

Project Goal . . . . . . . . . . . . . . . . 39

Difficulties in Conducting Research ........... 42

III $\quad$ METHOD ............................. 44

Subjects and Setting $\ldots \ldots \ldots \ldots \ldots \ldots \ldots \ldots \ldots$

Newcomer Group .................. 47

Mainstream Group .............. 52

Procedure ....................... 54

Questionnaire Design ............... 56

Pilot Testing .................... 57

Means of Analysis ................. 57

IV $\quad$ RESULTS ......................... 58

Return Rate ..................... 58

Summary of Findings ................ 60

Additional Findings .................. 67

Differences Between Males and Females . . . . . 67

Differences Between Age Groups .......... 70

Differences Between Language Groups . . . . . . . 71

V DISCUSSION AND IMPLICATIONS . . . . . . . . . . . . 74

Discussion......................... 75

Classroom Dynamics ................ 75 
Adjustment to New Classroom . . . . . . . . . . 77

Difficulties in Documentation . . . . . . . . 80

Parental Choice ................. 81

Socio-Economic Status . . . . . . ....... 81

Discussion of Unanticipated Results . . . . . . . . 83

Gender ........................ 84

Age.......................... 85

Language Group ................. 86

Implications For Teaching $\ldots \ldots \ldots \ldots \ldots$. . . . 87

Suggestions For Further Research ............. 91

Conclusion. ....................... 93

REFERENCES ................................ 94

\section{APPENDIX}

A. Summary of ESL/Bilingual Program Models . . . . . . . . . . . . . . 99

B. Identification and Placement of ESL/Bilingual Students in the Portland Public School System . . . . . . . . . . . . . . . 101

C. Demographic Breakdown of Study Participants .............. 103

D. Consent Forms . . . . . . . . . . . . . . . . . . . . 105

E. Study Questionnaire ........................ 110

F. Pre- and Post Program Evaluations used by Project GOAL Project GOAL Objectives . . . . . . . . . . . . . . . 115

G. Newcomer Program Exit Criteria . . . . . . . . . . . . . . 120 
I. Immigration Statistics $\ldots \ldots \ldots \ldots \ldots \ldots \ldots \ldots \ldots \ldots \ldots, 14$

II. Changing Motives of Americanization Throughout American History $\ldots \ldots \ldots \ldots \ldots \ldots \ldots \ldots \ldots \ldots \ldots, 22$

III. Blaming the Victim in Minority Language Education (Cummins) ... 26

IV. Questionnaire Return Rate $\ldots \ldots \ldots \ldots \ldots \ldots \ldots \ldots .60$

V. Mean Responses By Group $\ldots \ldots \ldots \ldots \ldots \ldots \ldots \ldots . \ldots 2$ 


\section{LIST OF FIGURES}

FlGURE

PAGE

1 Illustration of Immigration Patterns $\ldots \ldots \ldots \ldots \ldots \ldots \ldots \ldots$

2 First Language Breakdown of Study Participants ......... 47

3 Mean Responses for Questions $1-14 \ldots \ldots \ldots \ldots \ldots \ldots \ldots 63$

4 Mean Responses for Questions $15-28 \ldots \ldots \ldots \ldots \ldots \ldots \ldots 64$

5 Mean Responses for Questions $29-37 \ldots \ldots \ldots \ldots \ldots \ldots \ldots 65$

6 Mean Responses for Questions $38-51 \ldots \ldots \ldots \ldots \ldots \ldots \ldots 66$

7 Mean Responses for Males and Females for Questions 1 - 14 .... 67

8 Mean Responses for Males and Females for Questions 15-28 ...6 68

9 Mean Responses for Males and Females for Questions 29-37 ...6 69

10 Mean Responses for Males and Females for Questions 38 - 51 ... 70

11 Mean Responses to Questions 19 and 43 by Age Group ....... 71

12 Mean Responses to Questions 5, 13 and 36 by Language Group . . . 72 


\title{
CHAPTER I
}

\section{A PRELIMINARY COMPARISON OF TWO ESL SCHOOL MODELS FOR}

\author{
NEWCOMER STUDENTS
}

\section{INTRODUCTION}

Oregon's Portland Public School District currently uses two educational models for transitioning newly arrived immigrant students with little to no English ability into mainstream school culture and expectations. Both systems are faced with the challenge of helping foreign students - some of whom have no school experience whatsoever handle the hurdles of learning English, American culture, and a public school curriculum. The first of these models, the newcomer ${ }^{1}$ program, busses these new students to a central location where they have bilingual assistance, small class sizes, basic English instruction and a special curriculum designed to meet the orientation needs of new students. For those students unable or unwilling to attend this specialized program, the second option is direct mainstreaming: entering the regular grade level classroom with American children and receiving additional English assistance from an ESL (English as a Second Language) teacher. The purpose of this study was to compare the effectiveness of these two programs and to attempt to quantify any significant differences between the two groups with respect to social and school adaptation.

\footnotetext{
1 'The term 'newcomer' was coined during the early 1980's, in light of the heavy influx of refugees from Southeast Asia. At the time the term referred mostly to newly-arrived refugees who could not speak any English, had missed school or were significantly below grade level, and often needed special services to meet some of their non-academic needs" (Friedlander, 1990b, p.6). This is the definition of "newcomer" that this paper will employ.
} 


\section{$\underline{\text { Rationale }}$}

Historically, the United States of America has been a country made up of large and ever changing populations of immigrants. These new arrivals have sometimes been welcomed but often unwanted. Chapter II of this paper will provide a general outline of the history of American immigration, the historical attitudes toward immigrants, as well as the educational trends of immigrants throughout the history of the United States. This paper will attempt to show that the issues surrounding immigration and immigrant education are not new. This historical review will be used as a background to illustrate some of the broader contextual issues surrounding the current debates on immigration and immigrant education, as well as the specific goal of evaluating two school programs that attempt to educate and integrate immigrant children into Portland's public school system.

Recently, a large immigrant population explosion that "can almost be regarded as the equivalent of a demographic revolution" (Friedlander, 1990a, p. 1) has occurred in this country. Historically, surges in immigration have had tremendous effects on American culture as a whole with considerable challenges for the public school systems. For example, the issues surrounding immigration and immigrant education have moved into the central mindset of mainstream America ${ }^{2}$. Articles in popular newspapers and

\footnotetext{
2 For the purpose of this thesis the term "America" will be used to refer specifically to the country of the United States of America unless otherwise noted.
} 
magazines, hotly debated state initiatives and ballot measures, and the growth of the English Only ${ }^{3}$ movement are all indicators of the topic's move into mainstream cultural discussions. Much of the current debate over immigration is focused on the nation's schools, and the availability of resources to support education for "illegal aliens".

"Nationwide, of the 43.6 million children attending public school, some 2.6 million are non-English-speaking - an increase of $76 \%$ in the past decade" (Hornblower, 1995, $p$.

42). The majority of this increase has occurred in major cities such as Los Angeles, New York, Chicago, Houston and Miami. However, smaller cities and towns are affected by immigration as well, and school districts are facing the associated economic and cultural challenges.

One of the direct effects of the increase in the immigrant population attending school is the necessity to establish or expand many new program models to meet the special needs of these children. These models stem from several different educational philosophies and have, therefore, led to a great deal of study and controversy. Most of the controversy has settled around the strengths and weaknesses of bilingual education and ESL programs. The majority of elementary education programs in the United States mainstream immigrant children into regular English only classrooms. Usually these children will then receive additional English support in the form of team teaching or pullout ESL. This mainstreaming method is especially popular in districts with a large

\footnotetext{
3 "English Only" refers to a current political movement to declare English the official language of the United States. In addition, passage of such an initiative would free states and other government agencies from the task of providing information in languages other than English.
} 
variety of native languages among their ESL students, due in large part to the logistical and economic difficulties in running a bilingual program for more than a few languages.

Bilingual education is a broad term which generally refers to programs which strive to support the children's native languages as well as the dominant culture's primary language (in this case English). Typical American bilingual programs range from transitional bilingual education (TBE) programs in which the children's native languages are used until their English skills are sufficient to get them through school, to developmental bilingual education (DBE) programs that seek to support the first languages throughout the children's schooling. There are a variety of definitions and interpretations of bilingual education between TBE and DBE. See Appendix A for a summary of bilingual and ESL program models.

Recently, there has been the addition of a supplementary ESL model: the newcomer program. Friedlander (1990a, p. 4) states that "newcomer programs can be loosely defined as temporary transitional programs designed to meet the unique needs of newcomer students in the context of a nurturing and supportive educational environment." Newcomer programs are designed as an initial introduction to American school culture. Many newcomer programs share similar goals. Among these goals are 1) developing English language proficiency, 2) orienting students to school, 3) providing students with academic skills to carry on to mainstream or bilingual programs, 4) enhancing self-esteem, 5) developing inter-cultural communication and understanding (Friedlander, 1990a, p. 5) and 6) easing the student's transition into the American school system. The intent is to bring newly arrived immigrant children together into one setting, 
thereby creating a secure environment in which each child is included. They are not considered "outsiders," but rather contributing members of the group. Because all of the students are in similar situations, the children have the confidence to explore their new environments without being criticized for making mistakes. Unfortunately, because newcomer programs are such a new phenomenon, there has not been a great deal of literature published on their effectiveness. There have been several reports describing newcomer programs (Chang, 1990; Friedlander, 1990a,b) as well as reports on the achievements of specific related programs (Portland Public Schools, 1990). However there have not been any reported experimental studies measuring the effectiveness of newcomer programs as a first step to immigrant children's American education. A recent New York Times article stated:

Although there is increasing interest in newcomer schools, they are largely uncharted territory. Experts say there are no studies to document whether immigrant children perform better in separate schools than they would if they attended classes for speakers of limited English in mainstream schools.

But anecdotes suggest many children have good experiences at the schools, which help them overcome traumatic experiences or educational deficits they may have suffered in refugee camps or rural villages in their native countries. (Belluck, 1995, p. 13)

It is with this lack of experimental evidence in mind that this study was designed.

\section{STATEMENT OF PURPOSE}

The purpose of this study was to determine the effects of newcomer programs on the students who participate in them. As mentioned above, newcomer programs are designed to assist students in a variety of educational and cultural areas including English language development, attitude toward school and school adjustment skills. Due to time 
and resource constraints, this study focused on one specific parameter, school adjustment. The study took place within Portland, Oregon's urban public school system which has given considerable support to ESL and bilingual education. Currently, six percent $(6 \%)$ of Portland's school children are considered Limited English Proficient (LEP) and this number continues to grow. Two groups of students were studied. One group participated in the Portland Public School's Newcomer Program which is currently housed at Carter Elementary School and Roslyn Middle School ${ }^{4}$. The second group was drawn from students who met qualifications as "newcomers" but were not participating in the newcomer program for reasons that will be discussed in Chapter III. The students from this second group will be referred to as the "pre-beginner" group in order to differentiate them from the students who attended the newcomer program. (See Chapter III for a more detailed explanation of this term). Instead of entering the specialized newcomer program, these pre-beginners were immediately mainstreamed into regular elementary classrooms while receiving additional ESL support, usually through pull-out programs. After six months of school attendance, these two groups were compared on their social and school adjustment skills using a teacher questionnaire which was designed using original Project $\mathrm{GOAL}^{5}$ assessment materials. The original intent of this study was to answer the following question: after six months of school attendance in the United States, would there be a difference in the social and school adjustment skills of LEP students who had participated in the newcomer program and

\footnotetext{
${ }^{4}$ Pseudonyms has been used for the specific names of schools and people in order to protect their privacy.

${ }_{5}^{5}$ Project GOAL (General Orientation Assessment Literacy) was the title of the original Title VII grant upon which the current Portland Newcomer Center is based.
} 
the pre-beginner group who had not participated the newcomer program? This question was measured by a teacher questionnaire designed to determine the student's progress. Teachers used a Likert ${ }^{6}$ scale to rate the students in such areas as behavior, interpersonal skills, academic ability, and knowledge of school routine. The completed questionnaires were statistically analyzed using a Two-Sample $t$-test as the parametric measure and the Mann Whitney $U$ test as the corresponding non-parametric measure. Additional questions arose during the course of the study. These additional questions as well as a more detailed explanations of the study design and the measures used will be presented in Chapter III.

\section{Summary}

An historical overview of immigration and immigrant education is presented in Chapter II. This overview is followed by a description of current models and approaches used in the education of immigrant children, difficulties incurred when conducting research in this area, a description of Project GOAL (upon which this study is based), and a description of the ESL/bilingual programs within the Portland Public School District. Chapter III presents a detailed explanation of the methods and procedures used in conducting this study. This includes a description of the instruments used to measure the collected data and the processes used for the analysis of the data. Results obtained from the data are presented in Chapter IV. This chapter includes response rate, data

\footnotetext{
${ }^{6}$ The Likert scale is often used in questionnaire research. The questionnaire respondent is asked to indicate their reaction to the question by circling or otherwise marking a numbered scale (the Likert scale).
} 
analysis and statistical results. Finally, a discussion of the results and their implications for the teaching of immigrant children is included in Chapter V.

\section{DEFINITION OF TERMS}

For the purposes of this study, the following terms will be used:

\section{DEVELOPMENTAL BILINGUAL EDUCATION (DBE): or “maintenance}

programs" continue throughout the child's schooling. This places equal emphasis on the two languages and works to ensure that the child's first language is not displaced by the child's additional languages.

ENGLISH AS A SECOND LANGUAGE (ESL): "focuses on teaching students English using a variety of instructional strategies, such as simplified... English, gestures, and pictures, to convey academic content in the absence of native-language teaching" (Walling, 1993, p. 10). ESL is usually taught in conjunction with the instruction the student is receiving in his or her regular classroom. At the elementary level, ESL can take several forms: "pull-out," in which the child leaves the regular classroom for a specified period of time each day to study English; "team teaching," in which the ESL teacher enters the mainstream room for part of the day in order to teach with the mainstream classroom teacher and/or work one-on-one with ESL students within the mainstream classroom; "consulting," in which the ESL teacher works closely with the regular classroom teacher in planning strategies for the child; and "resource," in which students can drop by an ESL resource room for special help.

EXIT: the term used for graduation from a newcomer program or an ESL program as a whole. Students are exited from the Portland Newcomer Program when the student, 
teachers, and parents all agree that the child is ready to participate in the mainstream classroom.

LIMITED ENGLISH PROFICIENCY (LEP): a term used to describe English as a second language learners who have not yet achieved full English proficiency.

MAINSTREAM CLASSROOM: the regular American classroom that the student is assigned to.

NEWCOMER PROGRAM: “separate, relatively self-contained educational interventions designed to meet the academic and transitional needs of newly arrived immigrants" (Chang, 1990, p. 50). Students typically participate in newcomer programs for three months to two years before moving on to more traditional intervention programs.

PRE - BEGINNER: the term assigned to the students in this study who met the criteria for attendance in the Newcomer Program yet did not attend. Instead, these students were directly mainstreamed into their regularly assigned ESL schools.

PROJECT GOAL: the original Portland Public School District's Title VII project which eventually became known as the Newcomer Program. GOAL is an acronym for General Orientation Assessment and Literacy.

SUBMERSION: "subject matter class periods delivered in L2 (second language) in which teachers: (1) mix native speakers with second language acquirers, (2) speak in a native speaker-to-native speaker register, and (3) provide L2 acquirers with only minimal amounts of "comprehensible second language input"' (Evaluation, 1988, p.217). 
TRANSITIONAL BILINGUAL EDUCATION (TBE): a program in which the student is taught in the first language (L1) as well as the second language, in this case English (L2). As the student's proficiency in the L2 increases, the use of the L1 decreases. Usually, use of the first language is discontinued when the second language is advanced enough to ensure survival in the mainstream classroom. 


\section{CHAPTER II}

\section{LITERATURE REVIEW}

\section{Introduction}

The continuing political debates over issues surrounding immigration in the United States often seem to imply that these issues are new and unique to this time in our history. This belief is often implicit in the discussions of immigrant and bilingual education as well. However the issues of immigration and the education of immigrants and their children have been discussed in the United States and the world for centuries. This chapter outlines a brief history of immigration and immigrant education in the U.S., and presents current educational trends of immigrants in the United States. This history also includes a look at the changing popular views toward immigrants and lays the foundation for modern political issues that involve immigrants to the U.S. This overview is followed by a look at current models and approaches used in the education of immigrants and the difficulties incurred when conducting research in this area. Finally, the history of Project GOAL (upon which this current study is based), and a description of the ESL/Bilingual programs within the Portland Public Schools is given.

Historical Overview of Immigration

Without an understanding of the historic attitudes toward aliens, current language policies toward immigrants are difficult to analyze. Popular attitudes and the policies of this country have often gone hand in hand; thus an historical overview of immigration is necessary to a complete understanding of the immigration issues facing this country today. From its earliest days, when the ancestors of today's Native 
Americans first crossed over the Bering Strait from Asia to North America, the American continents have been beacons for immigrants. It was, however, the arrival of the Puritans from England in the $16^{\text {th }}$ and $17^{\text {th }}$ centuries that "laid the foundations for the continuing ethnic practices in American society" (Dinnerstein, Nichols \& Reimers, 1990, p. 4). The Puritans brought with them a religious and ethnocentric ideology which contributed greatly to America's developing sense of cultural superiority. For example, Dinnerstein et al.(1990) write that many of the early arrivals to the New Country "would have agreed with the cleric who in 1558 told his flock 'God is English."' (p. 4)

Although the main objective of the seventeenth century Puritan immigration was religious freedom, Puritan leaders ironically felt it was their moral obligation to structure their new country as a "model Christian commonwealth" by any and all means necessary. This assumption of superiority over people with cultures and beliefs different from the standard American ethic has held throughout America's history:

Cotton Mather and other leading New Englanders of the seventeenth century thanked God for their capacity to destroy, without flinching, the "heathen Tawnies" who blocked their efforts to build a model Christian commonwealth. The Puritan settlers of the country justified their harshness on the grounds that these Indians were agents of the devil, sent to torment the "chosen people" of God. Some three hundred years later, in 1968, a United States Army major reflected this traditional American view of the nation as a chosen people when he defended his order to attack a friendly Vietnamese town overrun by a force of Viet Cong soldiers. "It became necessary to destroy the town to save it," he said, assuming responsibility for the killing of the villagers. He decided it was better that they should die than live under the rule of the Communists, America's twentieth century devils. The rhetoric of the army major, associated less with military strategy than with missionary zeal, fits well into the history of a nation that, from the beginning, considered itself charged with responsibilities beyond those of other nations. (Carlson, 1975, p. 3)

The early subject of the Puritan's "missionary zeal" was the Native American community. However, as the Native Americans became more assimilated to the emerging American ideal, the common enemy shifted to encompass the new immigrant 
groups beginning to arrive. According to the U.S. Bureau of the Census (1975), "although the reporting of alien arrivals was required by the Act of 1798, which expired two years later, the number arriving before 1819 is not known" (p. 97). An uninterrupted record of immigration did not begin until the passage of the Act of 1819 . This act "required the captain or master of a vessel arriving from abroad to deliver to the local collector of customs a list or manifest of all passengers taken on board" (p. 97). The subsequent Act of 1855 required a quarterly report to the Secretary of State and annual reports to Congress. See Table I for a breakdown of the areas of origin for immigrants entering the United States from 1820 to the present.

According to Hartmann (1967), the first wave of U.S. immigration, commonly referred to as the "old immigration," occurred during the colonial period and the first three-quarters of the nineteenth century. This group consisted mainly of immigrants from northwestern Europe, especially the British Isles, Holland, and Germany. These were predominately Protestant Christians with a similar background of political, social and economic experience. One group, the Irish Catholics, recognized in part by their distinct accents, differed from these cultural similarities in their religious beliefs. For this reason, the Irish immigrants suffered intolerance from the already established Americans in the form of riots and beatings. This growing feeling of Nativism led to the creation of the Know-Nothing political party of the 1850 s. The Know-Nothings were openly hostile toward immigration and had successes in several elections. By the mid 1850s however, many of the Know-Nothing leaders were switching to the newly formed Republican party, and the Know-Nothing party soon fell out of existence. Intolerance toward the 
TABLE I

Number of Immigrants Entering the United States

\begin{tabular}{|c|c|c|c|c|c|c|c|c|c|c|c|}
\hline Year & Total Immigrants & Asia & Africa & America & Australiasia & NW Europe & Central Europe & Eastern Europe & Southern Europe & Total Europe & Other Countries \\
\hline 1820 & 8,835 & 5 & 1 & 387 & 0 & 6,499 & 973 & 15 & 204 & 7,691 & 301 \\
\hline 1821-1830 & 143,439 & 10 & 16 & 11,564 & 0 & 88,891 & 6,777 & 95 & 3,054 & 98,817 & 33,032 \\
\hline $1831-1840$ & 599,125 & 48 & 54 & 33,424 & 0 & 337,285 & 152,823 & 284 & 5,296 & 495,688 & 69,911 \\
\hline 1841-1850 & $1,713,251$ & 82 & 55 & 62,469 & 0 & $1,157,436$ & 434,731 & 610 & 4,724 & $1,597,501$ & 53,144 \\
\hline $1851-1860$ & $2,598,214$ & 41,455 & 210 & 74,720 & 0 & $1,479,669$ & 952,831 & 540 & 19.620 & $2,452,660$ & 28,921 \\
\hline 1861-1870 & $2,314,824$ & 64,630 & 312 & 166,607 & 36 & $1,244,174$ & 797,295 & 2,641 & 21,160 & $2,065,270$ & 17,969 \\
\hline $1871-1880$ & $2,812,191$ & 123,823 & 358 & 404,044 & 10,914 & $1,352,191$ & 804,121 & 39,632 & 76,318 & $2,272,262$ & 790 \\
\hline 1881-1890 & $5,246,613$ & 68,380 & 857 & 426,967 & 12,574 & $2,325,663$ & $1,858,495$ & 221,192 & 331,696 & $4,737,046$ & 789 \\
\hline 1891-1900 & $3,687,564$ & 71,236 & 350 & 38,972 & 3,965 & $1,138,340$ & $1,194,579$ & 521,826 & 704,233 & $3,558,978$ & 14,063 \\
\hline 1901-1910 & $8,795,386$ & 243,567 & 7,368 & 361,888 & 13,024 & $1,568,537$ & $2,486,764$ & $1,769,570$ & $2,311,145$ & $8,136,016$ & 33,523 \\
\hline $1911-1920$ & $5,735,811$ & 192,559 & 8,443 & $1,143,671$ & 13,427 & 853,493 & $1,050,414$ & $1,012,478$ & $1,460,179$ & $4,376,564$ & 1,147 \\
\hline $1921-1930$ & $4,107,209$ & 97,400 & 6,286 & $1,516,716$ & 8,726 & 871,821 & 854,742 & 174,673 & 576,617 & $2,477,853$ & 228 \\
\hline 1931-1940 & 528,431 & 15,872 & 1,750 & 160,037 & 2,417 & 84,498 & 162,736 & 20,584 & 88,108 & 348,289 & 66 \\
\hline 1941-1950 & $1,035,039$ & 36,471 & 7,367 & 354,804 & 14,551 & 263,221 & 272,401 & 6,338 & 79,744 & 621,704 & 142 \\
\hline $1951-1960$ & $2,515,479$ & 150,681 & 14,092 & 996,944 & 12,976 & 446,359 & 600,636 & 10,084 & 271,194 & $1,328,293$ & 12,493 \\
\hline $1961-1970$ & $3,321,677$ & 421,464 & 28,954 & $1,716,374$ & 25,122 & 394,290 & 294,011 & 17,220 & 424,149 & $1,129,670$ & 93 \\
\hline
\end{tabular}

Imigration Statistics from U.S. Bureau of the Census. 
Irish began to change with the arrival of the second wave of immigrants known as the "new immigration."

As early as 1875 a new group of immigrants began entering the U.S. (See Figure 1 for an illustration of immigration patterns to the US) This new group, emigrating from the eastern and southern European areas of the Russian Empire, Austria-Hungary, Italy and the Balkans, was considered "backward" (Hartmann, 1967, p. 14) and undesirably different from the previous immigrant groups. Hartmann (1967) explains that these "new immigrants" came from backgrounds with "little experience with self-government," "high illiteracy rates," and "lower standards of living" (p. 15). These groups positioned themselves in the cities where they began to form an unskilled labor force for the new and quickly growing industries. This relatively sudden influx led to overcrowding in the cities and exploitation of the new immigrants. The living conditions were deplorable and the rents were high. In addition, because the new arrivals were willing to work long hours for lower wages, tensions arose between the immigrants and American labor leaders.

At about this same time, the first anti-immigrant political organization, the American Protective Association (APA) began to gain prominence. Although the APA began as an anti-Roman Catholic movement targeting the mainly Irish Roman-Catholic immigrants, it gained broader public support for its strong stance against immigration. The labor movement supported the APA's political plank that "advocated the prohibition of further importation of 'pauper' labor" (Hartmann, 1967, p.20), and in a historically puritanistic manner, the plank also called for "the exclusion of teachers in public schools who were subjects of an un-American ecclesiastical institution" (Hartmann, 1967, p.20). By 1896, the APA began to fade from the political scene, but its legacy is still with us in 


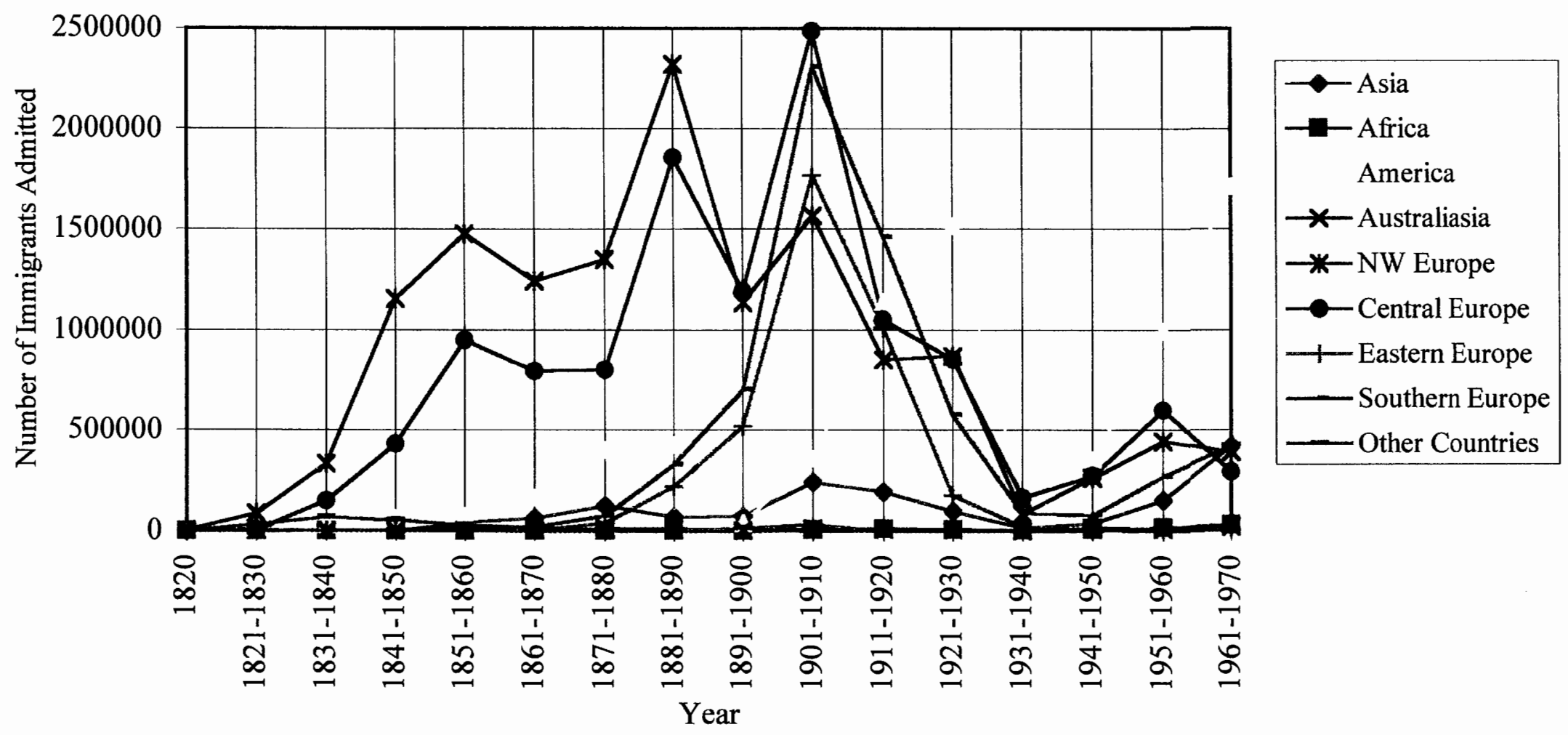

Figure 1. Illustration of Immigration Patterns into the U.S., 1820 - 1970. 
current debates over immigration.

Simultaneous with the founding of the APA was an opposing movement founded on the idealistic principles of helping immigrants to escape their societal exploitation and build better lives for themselves. These new immigrant advocates returned to a version of Americanization, urging that full assimilation into American society would make life easier and more fulfilling for the immigrant. This new idealistic perspective was probably best represented in the creation of settlement houses, the most well known of which was the Hull House of Chicago. The Hull House was started by young middle class college graduates who wanted to improve the lives of the immigrants. They tried to achieve this ideal by teaching "about republican government, the nation's Protestant heritage, AngloSaxon law, and middle class views of the rights and responsibilities of U.S. citizenship" (Carlson, 1975, p. 81). As time went on, the settlement workers began to adapt their programs to subjects more useful to the immigrants: "They provided manual arts programs, kindergartens, and classes in English, homemaking, and child care" (Carlson, 1975, p.82). This supportive perspective also led to the creation of the Educational Alliance of New York City, a group established in 1890 to "Americanize" the Jewish immigrants arriving from central and eastern Europe. The group raised money to build a large complex to house its many programs. The programs included adult ESL courses, classes for instructing teachers of immigrant students, "and special work with boys and girls to prepare them for attendance at the public schools" (Hartmann, 1967, p.26). As one of the first such agencies in the country, the Educational Alliance of New York City paved the way for many similar organizations to follow. One such organization, the YMCA, established a committee designed specifically for meeting the needs of immigrants. The North American Civic League for Immigrants was a direct result of this committee. The League pressured the Boston public schools to make education more 
accessible to their immigrant population. As a result, Boston became one of the first public school districts in the U.S. to explore options in immigrant education from a supportive rather than an ethnocentric point of view.

By 1914, the effects of World War I had begun to change attitudes and policies of U.S. immigration. The goals for Americanization had changed again (see Table II), this time as a way to assuage suspicion and encourage patriotism. Xenophobia was growing rapidly, and President Wilson's second veto of a literacy bill designed to keep southern and eastern Europeans out of the United States was overridden by Congress. The Literacy Bill of 1917 required any immigrant over the age of sixteen to demonstrate language skills by reading a short paragraph in English. Many other bills also passed which resulted in restrictions on immigration favoring northern Europeans and making entrance to the United States almost impossible for all other groups. During the chauvinistic hysteria of World War I, Germans were especially targeted for suspicion. Immigrants were closely watched by their neighbors, and if the foreign born were not careful, they "might be punished by the furtive painting of yellow stripes on [their] home to symbolize [their] 'disloyalty' " (Carlson, 1975, p.124). The official Americanization movement slowed after World War I when stringent immigration restrictions were placed on the U.S. However, the specter of communism kept fear and suspicion very much alive. During the xenophobic World War II years, 110,000 Japanese-Americans were forced to leave their homes and possessions and spend two years in government run relocation centers. Dinnerstein et al. (1990) quote the rationale for the relocation: "the Japanese race is an enemy race and while many second and third generation Japanese born on United States soil, possessed of United States citizenship, have become 'Americanized,' the racial strains are undiluted" (p. 252). 
After the war, the United States began liberalizing immigrant admissions with the passage of a series of new immigration acts. According to Reimers (1985), restrictions were eased on the admittance of displaced Europeans, as well as certain areas of Asia and the Pacific. In addition, many U.S. citizens were finally able to bring their families to America due to the passage of the War Brides Act of 1945. The United States also saw an influx of Mexican immigration due to the Bracero program which allowed Mexican workers to temporarily enter the U.S. as farm laborers. Europeans were the major immigrant group through 1965 when Congress passed new immigration legislation.

The Immigration and Nationality Act of 1965 phased out national origins quotas and provided instead a new system of 170,000 visas available for the Eastern Hemisphere and 120,000 visas for the Western Hemisphere. There were also provisions made to exempt immediate family members from the numerical limits (Reimers, 1985, p. 81). The passage of this act allowed for the entrance of a more varied group of immigrants, including more refugees and people from "Third World" countries. By the 1980s, European immigrants made up only $10 \%$ of those emigrating to the United States. The majority of new immigrants came from Asia and Latin America. In addition, American attitudes toward immigrants were gradually changing as well.

Although individual acts of violence toward immigrants continued, the national mood slowly began evolving from anglo ethnocentrism to cultural tolerance during the $20^{\text {th }}$ century. In Ethnic Americans Dinnerstein and Reimers (1988) explain:

The decline of prejudice can be explained by several factors. The fear of divided loyalties that was so potent in World War I and, to a lesser extent, in World War II did not materialize during the cold war. Prejudice is also strongly correlated with levels of income, religious intensity, and education. As incomes and education increased and as religion became less of a commitment and more of a social identification, tolerance grew. Education did not guarantee the end of prejudice, but there is no doubt that the rising levels of education served to dampen the fires of bigotry. A highly educated public seemed more willing to accept 
ethnic differences. At the same time, minority members absorbed the dominant values of society as they went through the public schools, state colleges, and universities. Finally, as a result of the immigration laws of the 1920 s, the nation had achieved a general balance of ethnic groups. (p.87)

Despite the growing acceptance and tolerance towards immigrants in the U.S., prejudice and fear still exist. The focus of the hatred has shifted with the times. South and Central Americans have taken blame for the illegal drug trade of the 1980s and 1990s. ArabAmericans suffered great suspicion during the Gulf War of 1990. Haitian and African immigrants are feared to carry the AIDS virus. Perhaps the group seen as the greatest threat in the 1990s is Mexican. Thousands of Mexicans, legal and illegal, enter the United States every year to work in agricultural positions. The influx of this group, especially in California, has caused fear and hatred. This fear is seen in the growth of the "English Only" movement which is attempting to make English the official language of the United States. An organization known as U.S. English, was formed in the 1980 s to lobby for the passage of an English only policy in the U.S. The passage of such a policy would theoretically relieve the American government of any language responsibilities toward immigrants. This could include the removal of such services as bilingual government documents and bilingual interpreters in schools, hospitals and courts of law. On August 1, 1996, the U.S. English bill (H.R. 123) passed the United States House of Representatives. The Senate version of the bill (S. 356) is expected to be voted on later in the year. A more recent example of the alien fear was the 1994 California passage of Proposition 187. The California Voter Information (1994) pamphlet proposes that this initiative prohibits state and local government agencies from providing publicly funded education, health care, welfare benefits, or social services to any person that they do not verify as either a U.S. citizen or a person legally admitted to the U.S. The measure also requires state and local agencies to report suspected illegal immigrants to the INS and certain state officials. 
Several other states, including Oregon, proposed similar initiatives for future ballots.

These proposals have not made it to the final phases since the U.S. Supreme Court has recently found the California measure unconstitutional.

In spite of the fact that the United States is and has always been a nation of immigrants, those who came before continue to be distrustful of the new generations. The motives for Americanization have changed often as a result of the political climates of the times. These changes have been summarized in Table II. Yet the end results have always been similar: assimilate the new arrivals as quickly and "painlessly" as possible. Today's climate values cultural diversity and appreciation for all people, yet these views are being constantly challenged. As recently as July 1996, a current presidential candidate called for a return to basics and "derided 'global awareness' and 'diversity' curricula that he charged have supplanted the basics - reading, writing and arithmetic" (Associated Press, 1996b). Once again, popular attitudes toward immigration are having a direct effect on the public school systems. 
Table II

Changing Motives of Americanization Throughout American History

\begin{tabular}{|c|c|c|}
\hline \multicolumn{3}{|c|}{ Changing Motives of Americanization, an Overview } \\
\hline Stage: & Impetus: & Motive: \\
\hline \hline st & $\begin{array}{c}\text { puritan } \\
16^{\text {th }} 17^{\text {th }} \mathrm{C}\end{array}$ & $\begin{array}{c}\text { save the souls of the heathen immigrants } \\
\text { (Dinnerstein et al., 1990) }\end{array}$ \\
\hline 2nd & $\begin{array}{c}\text { labor } \\
\text { mid-late 1800s }\end{array}$ & $\begin{array}{c}\text { discourage radicalism, save jobs } \\
\text { (Hartmann, 1967) }\end{array}$ \\
\hline 3rd & $\begin{array}{c}\text { idealism } \\
\text { 1ate 1800s-early 1900s }\end{array}$ & $\begin{array}{c}\text { help immigrants to overcome hardships } \\
\text { (Hartmann, 1967; Carlson, 1975) }\end{array}$ \\
\hline 4th & $\begin{array}{c}\text { WW I \& II } \\
\text { early 1900s }\end{array}$ & $\begin{array}{c}\text { patriotism/suspicion/xenophobia } \\
\text { (Carlson, 1975) }\end{array}$ \\
\hline 5th & $\begin{array}{c}\text { cold war } \\
\text { late 1900s }\end{array}$ & $\begin{array}{c}\text { save the world from communism } \\
\text { (Carlson, 1975) }\end{array}$ \\
\hline 6th & $\begin{array}{c}\text { globalism } \\
20^{\text {th }} \text { Century }\end{array}$ & $\begin{array}{c}\text { appreciation of cultural diversity/common means of } \\
\text { communication (Clayton, 1996; Dinnerstein \& } \\
\text { Reimers, 1988) }\end{array}$ \\
\hline
\end{tabular}

Historical Overview of Immigrant Education

It appears clear that the early development and strength of Puritan morals and beliefs have played a major role in the history of the United States. Ethnocentric Protestantism has been the conceptual base for the language planning and educational policies of the United States since its conception, and has continued to play a large role throughout our history.

The Puritan assumption of superiority was clear in the early educational practices of the United States. Puritan schools were created to train children in the acceptable practices of society as well as to pass on important religious values. This same ideal was expanded as a way to train new immigrants in the ways of mainstream America.

This commitment to education would sweep through other parts of America as New Englanders and their Presbyterian brethren settled in other colonies and in territories to the west. From New England's education of her people in the ways of the Lord would come the United States of America's education of her people in 
the ways of the nation. (Carlson, 1975, p.27)

This process, later to become known as "Americanization," has remained with this country throughout its history. Benjamin Franklin, who was brought up in a Puritan household, was among the first leaders to speak out for the Americanization of new immigrants. In their book Natives and Strangers, Dinnerstein et al. (1990) quote Franklin as asking, "Why should Pennsylvania, founded by the English, become a Colony of Aliens, who will shortly be so numerous as to Germanize us instead of our Anglifying them?" (p. 22). This issue was addressed by the creation of the "Society for the Propagating of Christian Knowledge among the Germans" which proposed the creation of separate free schools designed to Americanize the German communities. German leaders rejected the idea causing the last German free school to be closed down in 1763 . This desire to separate and Americanize new immigrants from the rest of the population was the beginning of a larger American trend.

Eighty years later, Americanization was again an issue in public education. The American Roman Catholic church objected to the use of the Protestant Bible in public education and as such advocated for the creation of private parochial schools for Catholic children. Rather than allow the separation as was the desire with the Germans, the Protestant majority refused it:

After all, Protestants regarded the public schools as one of the best ways of assimilating foreign children to the dominant culture. The Minnesota Chronicle and Register observed in 1850 that the common school "takes the child of the exile of Hungary, of the half-starved emigrant from the Emerald Isle, and of the hardy Norwegian, and places them on the same bench with the off-spring of those whose ancestors' bones bleached upon the fields of Lexington.... As the child of the foreigner plays with his school fellow, he learns to whistle "Yankee Doodle" and sing "Hail Columbia," and before he leaves the school-desk for the plough, the anvil or the trowel, he is as sturdy a little republican as can be found in the land. (Dinnerstein et al., 1990, p.120)

The desire to socialize and integrate these children into American ideals led to their 
inclusion in many public school programs. However, by the mid-1800's, records show school officials had become frustrated with the predominantly Irish and German arrivals:

...many of these children come from homes of vice and crime. In their blood are generations of iniquity... They hate restraint or obedience to law. They know nothing of the feelings which are inherited by those who were born on our shores. (Lazerson, 1971, p.33)

This tendency to blame immigrants for the problems of society began to grow stronger with the arrival of the "new immigrants" from southern and eastern Europe. Once the effects of the second wave of immigration began to be felt, the motives for the Americanization of immigrant children began to change. Because the cultures and educational values of the new immigrants differed widely from those who came before them, the new group began to take the blame for the social problems that were beginning to be experienced with the growth of new and bigger cities. Whereas the Puritan leaders felt the need to religiously enlighten the heathen immigrants from the first wave, the new group needed Americanization, they argued, for the prevention of truancy and the protection of the people.

It is largely through immigration that the number of ignorant, vagrant and criminal youth has recently multiplied to an extent truly alarming in some of our cities. Their depravity is sometimes defiant and their resistance to moral suasion is obstinate. (Tyack, 1974, p.75)

Since so many of the urban truants were poor, of immigrant stock, and nonProtestant - in Boston in 1849, 963 of 1,066 truants had foreign-born parents - school officials were tempted to put them in separate classes or separate institutions despite the common school ideology of mixing all social groups under one roof. (Tyack, 1974, p.69)

As mentioned in the previous section, not all reactions to immigrant children were negative. The Educational Alliance of New York City organized what could be regarded as an early precursor to today's newcomer programs in their public school preparation classes for immigrant children. In addition, Carlson (1975) reports that John Dewey used the settlement houses as an example of desirable schools. Dewey argued that schools 
should bring "people together, [by] doing away with barriers of caste, or class, or race, or type of experience that keep people from real communion with each other" (pp. 86-87). States also began offering bilingual classes for the children in their districts as a means of easing the acculturation process. However, providing this native language instruction for children in the public schools was seen by many as a divisive tactic. For example, in his book One Best System, Tyack (1974) quotes a 1914 educational article from Rural Teacher of Nebraska:

How can we have national spirit in a Commonwealth where there is an infusion of the language and blood of many nations unless there is a very strong effort made to socialize the different elements and weld them into a unified whole....(p.22)

It was generally believed that bilingual education would work against the effort to unify the country by leading to social fragmentation. Many educators and politicians pointed to the difficulties experienced by many second language learners as proof that children could not learn two languages simultaneously (Hakuta, 1986). As seen in Table III below, children were often forbidden to speak their home languages at school. In their effort to help children succeed in school by fitting into the American culture and English language, school officials were instead contributing to the failure of these students. However, recent studies contributing to our knowledge of sound language learning theory have helped to change many of these past educational perspectives on bilingual education. 
Table III

Blaming the Victim in Minority Language Education

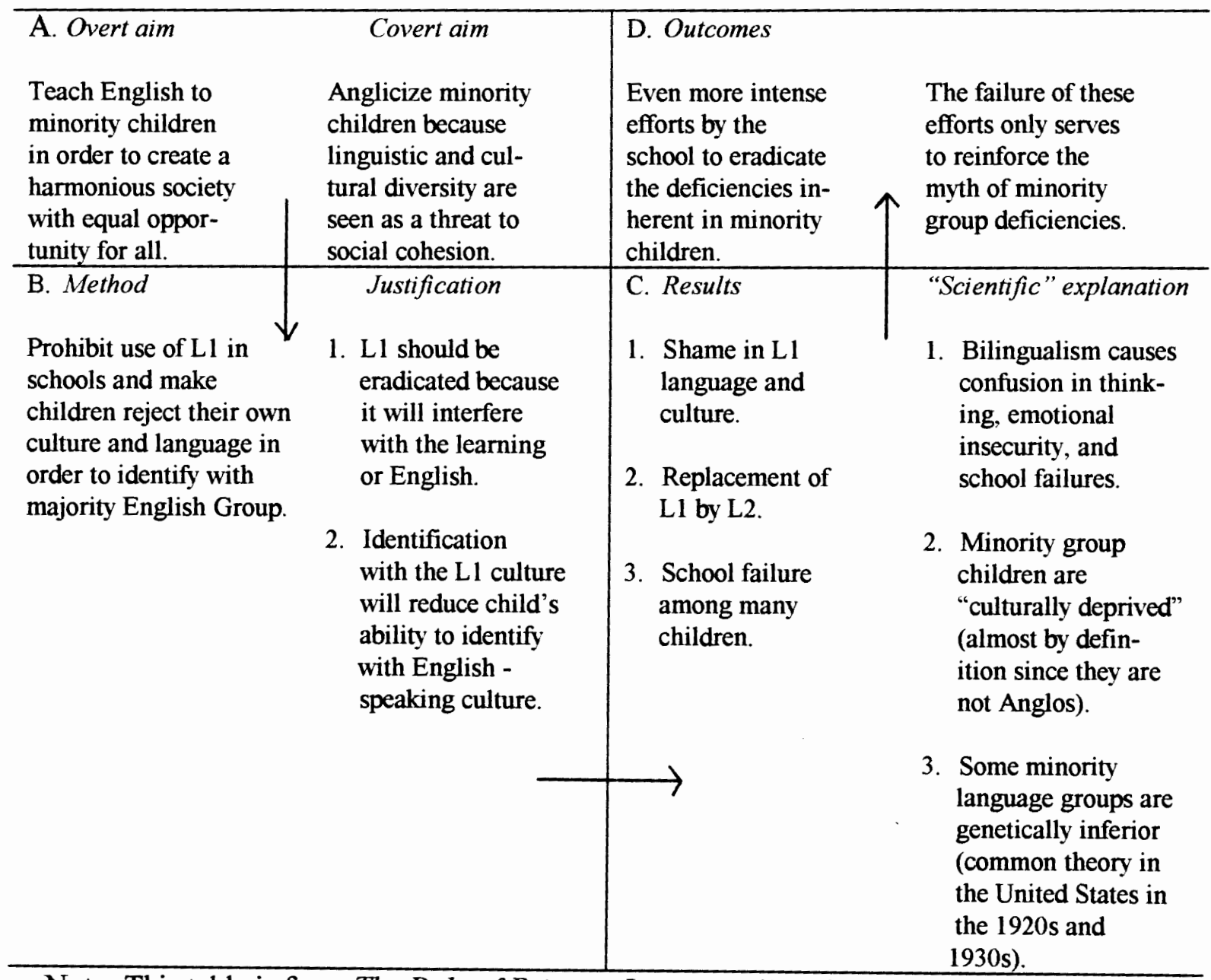

Note. This table is from The Role of Primary Language Development in Promoting Educational Success for Language Minority Students (p. 21) by James Cummins, in Schooling and Language Minority Students: A Theoretical Framework, 1988, Sacramento, CA: California State University.

In recent years, researchers have learned a great deal about the language learning process. The view toward bilingualism and bilingual education has changed. Today, most researchers agree that instead of bilingualism being detrimental to a child's learning of a second language, a firm grasp of the first language is instead a necessity to the complete acquisition of the additional language (Krashen, 1991; Hakuta, 1986). This alteration in the view of language acquisition has caused a recent shift in the teaching of immigrant 
students. Whereas in the past students were often submerged in mainstream English only classrooms to "sink or swim," today immigrant students are provided with ESL support and when available, bilingual classes. Much of the concern for the well-being of these students is the result of a 1974 Supreme Court ruling in the case of Lau v. Nichols. Lau V. Nichols

In Title VI of the Civil Rights Act of 1964, the Supreme Court of the United States ruled that equal opportunities for education must be available to all citizens, regardless of race, color or national origin in "any program or activity receiving federal financial assistance." In 1974, this decision was brought to the defense of non-English speaking immigrant children in Lau v. Nicols in which it was decided that Chinese students had been discriminated against by the city of San Francisco school district's "failure to provide special English instruction to students of Chinese ancestry who do not speak the English language." (Kauper, 1980, p.930) It was argued that because education in the United States is conducted in English, those who do not speak English are not receiving their equal opportunity for education (Witt, 1990, p.597). Therefore, districts with nonEnglish speaking students must take affirmative steps to rectify the language deficiency. The following year, guidelines were issued by the Office of Civil Rights (OCR) holding school districts accountable for the special language needs of language minority students.

The issuance of the OCR's guidelines caused many educators to take a closer look at recent research in the area of second language acquisition. Many of the newer ESL and bilingual models are a direct outgrowth of this new knowledge.

\section{Second Language Acquisition Research}

As mentioned above, a great deal has been learned in recent years about the acquisition of multiple languages. The most influential result of current research is most likely the realization of the importance of the student's $\mathrm{L} 1$ in the acquisition of additional 
languages.

The common assumption used to be that languages were learned separately from one another and therefore multiple language learning made the acquisition of more than one language difficult and detrimental to the full acquisition of any of the languages under study. Today, this belief has been replaced by the understanding that the brain has an underlying capacity for language learning that is common to all languages (Cummins, 1988). In the 1960s, this hypothesis of an innate ability to learn language was described by Chomsky as the Language Acquisition Device (LAD). Chomsky believed that infants receiving comprehensible input in their native languages would process the information through LAD, eventually formulating the rules of the language which would enable them to communicate. Later, this hypothesis was expanded to include second language learners as well. Cummins (1988) describes a "common underlying proficiency" (CUP) for language acquisition and argues that "experience with either language can promote development of the proficiency underlying both languages, given adequate motivation and exposure to both either in school or in the wider environment" (p. 25). See Cummins (1988) and Krashen (1988) for a more detailed explanation of these theories. Moreover, recent research has indicated that first language loss can contribute to educational difficulties and school failure in language-minority students (Wong Fillmore, 1991). Arguments for bilingual education are based upon these assumptions. If these theories are correct, bilingual education helps to build the strength of the first language while simultaneously keeping the child at grade level in his/her first language while $s /$ he becomes proficient in the L2. Although a discussion of bilingualism is beyond the scope of this paper, it is important to note that bilingual education not only serves the child by keeping him/her at grade level while learning the new language, but bilingual education also serves to validate the child's first language by making the speaking of that language acceptable in 
school.

Additionally, recent studies show that in order for a language to be acquired, the input received by the child must be comprehensible and the learner must feel secure in the environment (Igoa, 1995; Wong Fillmore, 1991; Krashen, 1988). If a student's anxiety level is high, or if the language input is out of reach of the learner, acquisition will not occur. Recently, cultural validation has been added to the strategies of second language education practices. Cummins reports that

when schools reinforce minority children's cultural identity, promote the development of the $\mathrm{L} 1$ communicative proficiency children bring to school, and make instruction in English comprehensible by embedding it in a context that is meaningful in relation to students' previous experience, then minority students experience academic success and develop high English literacy skills, in spite of sociocultural impediments. (Cummins, 1988, p.37)

This combination of factors in the teaching of LEP students is referred to as "cultural/academic/psychological [CAP] intervention by Igoa. Igoa (1995) argues that it is necessary to teach the "whole child" by focusing on cultural and psychological issues as well as academic growth. This is due in large part to the interconnectedness of these pieces in the acculturation process.

\section{Cultural Identity and Acculturation}

In addition to advancements in our understanding of the second language acquisition process, researchers have also gained new insight into the acculturation process experienced by new immigrants, and the effects acculturation has on their education. Clayton (1996) attempted to uncover "an underlying pattern of acculturation" (p. 3) by studying four newly arrived immigrant students through classroom observations and interviews with the students, parents and teachers. In her introduction, Clayton (1996) quotes a mainstream teacher of one of the new students as saying

Then, after lunch when it was time to come back to the classroom, 
he wrapped himself around a pole in the lunch room and would not let go. It took the principal and the guidance counselor and me to loosen him from the pole and march him upstairs. It's like he's from a different planet. (p.1)

This description of the new student as seeming "from a different planet" seems common among teachers of new arrivals. For this study, teachers described newcomer students as being "shy and quiet," "disruptive and mischievous," "very sensitive, easy to cry," and "lost in the ozone." All of these reactions fit into the pattern of acculturation. According to Clayton (1996),

...there seems to be a series of phases that the foreigner experiences: The phases begin with preparation and entry into the new culture, at which point the feelings are normal to high; a second phase, in which the foreigner is a spectator, wherein emotions vary from mostly high to very low; a third phase, in which increased participation makes the foreigner realize the magnitude of the differences between the host culture and home culture, which in turn starts a downward trend in emotional well-being; a fourth phase of shock, wherein the emotions are very negative. Then the adaptation (fifth) phase begins, in which the emotions return closer to normal as the foreigner learns to function in the host country. (p.50)

Different cultural groups and different individuals use varied strategies for dealing with the acculturation process. For children, who may have less ability to mask their emotions, these strategies may cause them to appear as though they are from "a different planet" to a person from the host culture. The behaviors that result in the early stages of acculturation can often be misunderstood by the classroom teacher and/or disruptive to a classroom routine.

\section{Silent Stage}

One of the early and most common manifestations of the acculturation process in children is the silent stage. There is often a period of several weeks to several months in which the child is not talking and often not participating in classroom activities. Igoa (1995) believes that this is a critical stage for the newcomer student:

I regard the silent stage as a period of incubation during which 
the child must be provided with a warm and nurturing environment that makes it safe for him or her eventually to break out of a shell as well as to accept himself or herself as belonging to a diverse society. Ultimately, supporting the child through this crucial period is more efficient than the "sink-or-swim" approach of placing the child into the "mainstream." Moving the child from class to class to speed up the learning of English often has the unintentional effect of making the child relive the uprooting experience again and again. (p.38)

\section{Socialization}

The acceptance of "himself or herself as belonging to a diverse society" mentioned by Igoa above, hints at a broader aspect of language learning. Wong Fillmore (1985) describes the task of language learning as "an enormously complex task consisting of figuring out and learning the full system of linguistic, social, and pragmatic rules that govern the language behavior of the speech community" (p. 3). Ochs and Schieffelin (1982) looked at the social aspects and implications of language learning in an ethnographic comparison of the language of children and their caregivers in three diverse cultural groups. The researchers found that "the process of acquiring language is deeply affected by the process of becoming a competent member of society" (p. 4). For example, with first language learners, the children's language

is influenced by social expectations. Children's strategies for encoding and decoding information, for negotiating meaning, and for handling errors will all be socially organized in terms of who does the work, when and how. (p. 67)

Wong Fillmore (1985) expands this theory to second language learners by explaining that "the learners make use of their social knowledge to figure out what people might be saying, given the social situation" (p. 4). If these socialization/language theories are correct, then it would be possible to conclude that social skills for functioning in the American classroom would indeed be necessary for the complete language acquisition by the newcomer/pre-beginner students. The difficulty for the educator, therefore, becomes the attempt to balance the teaching of American culture with the respect for the child's 
first culture.

The newcomer model has attempted to take all of these theories into account. A newcomer program allows for the acculturation process by allowing children a silent period, providing comprehensible input, introducing children to the social expectations of American schools, and providing work that they can be successful completing. In addition, bilingual assistance is provided in all possible cases to encourage development of the first language. Finally, the children's cultures and languages are validated through their encouragement to use their first languages and share their cultures.

\section{Program Models}

It is generally accepted by the language community that it takes an individual 4-6 years to gain academic control of a second or additional language (Wong Fillmore, 1986). In addition, "differences of up to five years can be found in the time children take to get a working command of a new language (Wong Fillmore, 1985, p. 8). Given this fact, it is essential to consider the most productive ways to encourage the development of the common underlying proficiency device. The program models chosen by different districts are a direct result of the district's goals for their LEP (Limited English Proficient) students and the resources available for the implementation of these goals. For example, does the district value the first language of the students enough to provide instruction in that language? Are there bilingual teachers available in the needed languages? Is the main objective to teach the students English as quickly and efficiently as possible? Is there money available to provide bilingual support for the students of the district? All of these are questions that school districts must look at when choosing program models for their LEP students.

As mentioned above, an early model used in the education of LEP students was the submersion, or "sink or swim" model. This was probably the most widely used model 
in early America. In submersion programs, non-English proficient students are assigned to mainstream American classrooms in which all instruction is in English. There are no provisions such as ESL or curriculum adjustments made for the children. Many people still believe that the submersion method is the best model to follow. It is argued that early immigrants survived submersion, and therefore today's immigrants should be able to as well. While it is true that most of the early immigrants to the United States were not provided any special allowances in the public schools, it must be remembered that the early European immigrants had the advantage of similar cultural backgrounds relative to one another. They had similar values, beliefs about education and expectations of society.

In contrast, today's immigrants come mainly from the diverse "Third World." Most come from lower socio-economic backgrounds compared to the early European immigrants. Often, the children come from small villages where there was no school. The stress of entering a new culture, not understanding the language and having never attended school can be overwhelming. In her book The Inner World of the Immigrant Child, Igoa (1995) quotes one of her students:

Putting an immigrant child who doesn't speak English into a classroom, a regular classroom with American students, is not very good. It scares the hell out of her or him because it is so different. [Teachers] should start [them] slowly and have special classes where the child could adapt and learn a little bit about American society and customs. (p.103)

Although it does not specifically address issues regarding American society and customs, a method that is sometimes employed to ease the transition is submersion with an ESL component.

English as a Second Language, or ESL, is a form of teaching English that does not require that the teacher have detailed knowledge of the student's first language (L1). Instruction "focuses on teaching students English using a variety of instructional strategies, such as simplified or 'sheltered' English, gestures, and pictures, to convey 
academic content in the absence of native-language teaching" (Walling, 1993, p.10). This strategy is most often used in districts which have a large variety of home languages spoken among their LEP students. The primary arguments for an ESL approach are 1) to alleviate the need for bilingual instructors in each of the potentially numerous languages that a district's students may speak, and 2) to encourage rapid English acquisition. This model serves well in districts and schools where bilingual education is not possible. ESL offers students individual attention to their particular needs. In this model, the ESL teacher may have an individual classroom in which s/he teaches students who are "pulledout" of the mainstream classroom. The students then receive specialized instruction in vocabulary, reading, speaking, pronunciation and listening. ESL models can take other forms as well.

Opponents of the pull-out method argue that students are missing valuable mainstream classroom instruction. To combat this problem, a variation called the "team teaching" model has recently become popular. In a team teaching approach, the ESL teacher works closely with the mainstream teacher in the mainstream classroom. In this model, the ESL students never have to leave their classrooms while receiving additional ESL assistance. The ESL teacher works within the mainstream classroom providing oneon-one assistance or small group activities with the ESL students. The teachers can work together to insure cohesive lesson planning and instruction. Whereas the submersion + ESL approach is a better alternative to the submersion method alone, it still faces opposition. It is argued that by ignoring a student's native language, a negative stigma to that language may be felt by the student. In addition, by receiving instruction in English alone, the student may be missing important topics and concepts that could be easily conveyed in his or her L1. Bilingual models, on the other hand, claim to address these issues by providing full or part-time instruction and support in the student's native 
language. These programs can take several forms, the most common of which are transitional bilingual education (TBE), and developmental bilingual education (DBE).

When looking at bilingual programs, it is important to identify the intended purpose. Krashen explains that

bilingual programs vary with respect to whether they are intended to maintain the children's first language indefinitely (maintenance) or are only to help them ultimately adjust to an all-English program (transitional). (Krashen, 1988, p.52)

Transitional bilingual programs are designed to ease students into the English only culture of American classrooms. When students enter the program they are primarily instructed in their native language. English is introduced and added slowly throughout the program. As the student's ability in English progresses, the use of the $\mathrm{L} 1$ is progressively phased out. The ultimate aim of TBE programs is to help the students become proficient enough in English to no longer require the L1 in school.

In contrast, developmental bilingual programs strive to maintain use of the first language throughout a child's school experience. In this model, the $\mathrm{L} 1$ and $\mathrm{L} 2$ receive equal importance in the student's studies. For example, a student may spend alternate days in English and Spanish classrooms. It is believed that by emphasizing both languages equally, the students will maintain their first language and cultural identity while learning the second language.

Recently however, a new model has been added to supplement the traditional ESL and bilingual approaches. Rather then having English acquisition as its main objective, this new model strives to ease the entrance of newly arrived immigrant children into the American school system by offering school orientation, multi-cultural communication, and a "safe" environment with other newly arrived immigrant children in addition to ESL and native language instruction. This new model is known as the newcomer program, and it is 
designed as a transitory step to aid in the initiation and acculturation of new immigrant students into the school system before they enter the more traditional programs.

Active debate continues to surround the issue of program models. The discussion has even begun to enter into the consciousness of the mainstream public and press as evidenced by recent articles in the New York Times, The Oregonian and Time Magazine (Associated Press, 1996a; Belluck, 1995; Di Rado, 1996; Hernandez, 1996; Hornblower, 1995; Jacobs, 1996). In fact, Time gives a concise synopsis of the problems by declaring:

Both English-immersion and bilingual methods will fail, however, if classes are too crowded, taught by unqualified teachers, lacking in appropriate materials, or filled with the wrong combination of students - conditions that are all too common. (Hornblower, 1995, p.49)

Description of a Newcomer Program

\section{Intake Criteria}

Although no two newcomer programs are the same, the literature agrees that they share many similar characteristics (Chang, 1990; Friedlander, 1990; Project Goal, 1990). The first of these is intake criteria. Because newcomer programs are designed to meet the initial needs of newly arrived immigrants, most programs accept "1) those students with limited or no English skills and 2) those who have had little or no previous schooling" (Chang, 1990, p.21). The students are assessed using English language proficiency tests such as the Language Assessment Survey (LAS) or the IDEA oral language proficiency test. Many programs also assess student's math knowledge as well as their native language ability.

\section{Program Model}

Secondly, all newcomer programs seem to fit into one of two models: 1) the separate site model or 2) the school within a school model (Friedlander, 1990). In addition, these programs can be either half day or full day programs. 
As the name implies, separate site programs exist on their own campuses away from the influence of mainstream schools. In the separate site model, students usually attend the newcomer program for half of the day and attend a mainstream school during the second half of the day. This is to insure some contact with mainstream students. In those separate site models that do have full day programs, the students are generally limited to one year of attendance in order to avoid long term segregation from the mainstream school environment.

In the school within a school model, the newcomer program is housed in a regular, mainstream school building. Because the newcomer students have many opportunities during the day to interact with mainstream students, these programs usually run the full day.

\section{Curriculum}

A third similarity between various newcomer programs is curriculum. Subjects such as rules, safety, school vocabulary, and culture are common topics covered in newcomer classrooms. In addition, because "a special curriculum needs to be provided that will develop children's subject matter knowledge through linguistically simplified instructional materials and second language teaching methodology" (Chamut ,1983, p.6), many newcomer programs attempt to keep students knowledgeable of mainstream grade level skills by presenting specially designed units and lesson plans.

Newcomer programs also tend to have smaller class sizes, some type of bilingual assistance, and access to a number of support services such as health and community outreach.

\section{Exit Criteria}

Exit criteria vary from program to program. Some programs mainstream students as soon as they can read and write, while others keep students until they are within one 
grade of standard grade level. With this variation, students can exit a newcomer program anywhere from three months to three years after entering. Most programs, however, put a one year time limit on newcomer attendance in order to avoid long-term social segregation, and make room for new students entering the program.

Portland Public School System

Like all districts in the United States, the Portland Public School District has experienced changes in attitudes and policies reflective of the times. Bilingual and multicultural classes are the norm in today's Portland Public School's ESL classrooms. Every attempt is made to respect the cultures and languages of all students.

The Portland Public School district, covering 152 square miles and containing over 100 schools and programs, is the largest school district in the State of Oregon. As of 1995 , the district served a population of over 56,000 students, 10,000 of which came from homes speaking languages other than English. 4,000 of these students have been identified as Limited English Proficient (LEP). Portland's ESL/Bilingual program, designed to meet the educational needs of these children, enrolls students in 42 different school buildings throughout the district. Additional programs are scheduled to open during the 1996-97 school year. Portland has over 50 language groups represented, the majority of which are Vietnamese, Russian, Spanish, Chinese, Lau, Hmong and Mien. The district employs many bilingual teachers to aid in the education and adjustment of these children.

The ESL/Bilingual Program of the Portland Public School System utilizes a variety of approaches in the implementation of their programs. The most widely used model is the pull-out model; however, team teaching has become popular in recent years. Portland also offers sheltered English classes at the secondary level, and several bilingual programs are available as the result of Title VII grants that have been awarded to the Portland 
Public Schools (Portland, 1995).

Assessment

All new students to the Portland Public School District are required to register with the district when they enter their new school. Families that indicate the home use of a language other then English are asked to bring their students into the ESL/bilingual office for further assessment. Students are assessed using "native language interviews, documents, and testing, information regarding the student's educational background including years of schooling, native language proficiency, and academic level" (Portland, 1995, p.9). If the student is determined to need additional ESL or bilingual assistance, parental permission is sought in the family's first language. If parents agree to ESL/bilingual placement, the student's placement is discussed and decided upon the same day (See Appendix B for a flow chart of Portland Public School's identification and placement process). Due to the many variations of previous schooling, English ability and learning styles, students may remain in the ESL/Bilingual program anywhere from three months to seven or more years. The exit review process can be initiated by the parents, students, ESL teacher, classroom teacher or bilingual staff members. Several factors are considered in the exit review. These factors include the agreement of the student and his/her family, a review of the student's mainstream grades, the student's achievement level on one of several possible standardized tests, and the opinions of the classroom, ESL and bilingual teachers. Once students exit the ESL/Bilingual program, their progress is monitored for several semesters to assure continued academic growth.

\section{Project GOAL}

Project GOAL (General Orientation, Assessment and Literacy), the original name given to the Newcomer Program, was started by the Portland Public School system in 1986 as a way to "provide newly arrived LEP students with basic English language skills 
and an orientation to the rules and expectations of American classrooms, to facilitate their transition and enhance their likelihood of success" (Project GOAL, 1990, p.1). The project was originally supported primarily by a Title VII transitional bilingual education grant with additional assistance from district funds. Although Title VII support has since ended, the Portland Public School District had continued to support the newcomer centers and even expand the program to include middle and high school students.

The three original instructional goals of Project GOAL were as follows:

1. The English language proficiency of participating students will be increased.

2. The native language literacy skills of the participating students will be improved.

3. The adjustive behavior of participating students will be improved (Project GOAL, 1990, p.4).

These goals were met using an instructional design similar to the one used currently in the newcomer centers (see Chapter III). The day consisted of two and a half hours of ESL, native language instruction, math, PE, music and school orientation classes. Based on the current beliefs about second language acquisition discussed above, Project GOAL's fourth year report states that this schedule was designed to accomplish the following objectives:

1. It familiarizes new immigrant students to the routines and expectations of American schools.

2. It provides some content instruction so that students will have a basis in the subjects they will be studying with English-speaking classmates.

3. It builds and reinforces native language literacy skills that will transfer into the application of such skills in English.

4. It lays the foundation in English proficiency, in both oral and written skills (Project GOAL, 1990, p.4). 
The effectiveness of this instructional design was evaluated by an external evaluator for the Project GOAL fourth year report. The evaluator observed the program and attempted to operationalize the three program objectives into an honest assessment of the program. Although the results of all three goals showed significant improvements, only the third goal, "the adjustive behavior of participating students will be improved," shall be discussed here since it relates directly to the topic of the current study.

Objective three stated that "each full-term participant will demonstrate mastery of key items in the Project's hierarchy of school adjustment behaviors" (Project GOAL, 1990,p.24). This hierarchy measured school adjustment behaviors using a scale from zero, meaning "never", to four, meaning "always". The behaviors were divided into five areas: work habits/social skills; basic school information; school procedures and rules; program and playground rules; and school lunch program. According to the evaluator, "one hundred and seventy-six students were both pre and post-tested on school orientation in 1989-90. All of them (100\%) showed gains, which ranged from one point to 18 points" (Project GOAL, 1990, p.24). The average gain among the students was shown to be significant beyond the .001 level of probability by a paired t-test. The evaluator goes on to explain:

The pre-test scores show that newcomer students at all grade levels entered the program with only moderate understanding of the expectations of school rules and behavior. The post-test scores show that students at all grade levels learned school behaviors at a near-mastery level. (Project GOAL, 1990, p.25)

This conclusion is meaningful to the current study because it illustrates a previous example of the success of a newcomer program in the area of social and school adjustment. In addition, the current study's questionnaire was a direct modification of the hierarchy used in the earlier study. 


\section{Difficulties in Conducting Research}

Because of the relatively recent development of newcomer programs, there is not much literature on the subject. California Tomorrow, a non-profit organization that conducts policy research on multicultural issues relating to California's schools, has published several informative documents related to immigrant children (Chang, 1990; Olsen, 1988,1989). Also used for this research has been a descriptive report on newcomer centers (Friedlander, 1990), and the fourth year report of the Portland Public Schools' Newcomer Program (Project GOAL, 1990).

There has been a great deal of research, however, in related areas such as structured immersion and bilingual education. One example is Gersten's $(1985,1984)$ research on structured immersion. In a structured immersion program, all instruction takes place in English that is at a comprehensible level to the students. This approach is used in newcomer and many ESL programs as well. Gersten also found that students involved in structured immersion programs achieved and maintained significant growth in several areas of the curriculum.

Walsh and Carballo (1986) did an extensive, preliminary study of the success of transitional bilingual education programs in Massachusetts. Using five districts in their sample, they compared the achievements of students who completed a TBE program to those who were directly mainstreamed instead. The researchers compared three measures to determine the success of the programs: attendance, grades, and English language ability. Their results showed that TBE was a successful model to use with LEP students. Interestingly, this study set off a debate on the problems inherent in bilingual research (Rossell, 1988; Snow, 1988; Walsh, 1988). Rossell complained that Walsh and Carballo's study sample was too small, that there was no statistical analysis of the data, no control between groups, and that the districts sampled suffered from "self-selection bias." This 
type of complaint seems common in ESL and Bilingual research. Because the populations being used for study are often transitory, it is difficult to find a stable sample. In addition, unless the permission of numerous school districts can be obtained, the selection of qualified study participants can be limited. In addition, self-selection can be a problem in any area that requires participant permission (See Chapter $\mathrm{V}$ for a more detailed discussion of this problem).

The comments of Rossell (1988) were carefully considered in the design of this study, as were the suggestions of several other authors (Alderson, 1992; Beretta, 1992; Baker \& de Kanter, 1981). As these articles illustrate, it seems difficult to achieve a consensus on the effectiveness of program comparisons.

\section{Summary}

History, public attitudes, financial considerations and current research all play a role in the language policy debates of this country. This study strives to focus on a small, educational piece of this larger political discussion. The following chapters will attempt to draw from the historical and background information presented here in order to illustrate how and why particular questions were asked and why particular answers were and were not found. 


\section{CHAPTER III}

\section{METHOD}

Introduction

This chapter discusses the methods used during the course of this study. First, an explanation of the participating subjects and ESL programs is given. This is followed by an account of the procedures used in the collection of data, a description of the instruments used to measure the collected data, and a description of the pilot study. Finally, the processes used for the analysis of data are described.

\section{Subjects and Setting}

The subjects for this program comparison came from two different types of elementary programs designed for newly arrived immigrant children in the Portland Public School System of Portland, Oregon. The student subjects were chosen when they were processed through the Portland Public School's ESL/Bilingual Assessment Center. Upon entering the school district, students who claim a dominant home language other than English are initially assessed by the ESL/Bilingual department. The assessment consists of a series of tests which include oral English proficiency (as measured by the IDEA Oral Language Proficiency Test), English reading and writing, native language reading and writing (when available) and math. The results of the IDEA Oral Language Proficiency Test as well as the IDEA Reading and Writing tests are used to determine ESL placement. Those students who qualify for ESL/bilingual services are given the option to accept or decline these services. Those accepting ESL service receive their 
school assignments the day of assessment.

To be classified with "newcomer" status, students must score on the low end (12 out of 5) of the IDEA Oral test (little to no English), must have been in the country for six months or less, and must not have previously attended school in the United States. However, in order to differentiate this broad group of newly arrived students from those students specifically enrolled in the Newcomer Program, this study will refer to the broader group as "pre-beginners". These pre-beginner students have two placement options within the ESL program. The first of these options is placement into a specific newcomer center. Students who attend this newcomer program are bussed to one of several district-wide assigned newcomer sites. At the newcomer site, the students are placed within a self-contained classroom where they receive comprehensive instruction in ESL, math, native language skills (when available), American school culture skills, physical education and music. The newcomer students remain at the center until their English skills and social behavior are adequate for mainstreaming. The students are then exited to their regularly assigned ESL schools, a period usually requiring three months to one year after entry into the newcomer center.

A second ESL option is available to pre-beginner students who do not choose to attend or are unable to attend the newcomer program. These students are assigned directly to their regular ESL school in which they attend a mainstream American classroom while receiving supplemental ESL assistance in one of several possible models. The crucial distinction between these two pre-beginner groups is in the application of specific teaching techniques and goals in the newcomer program which are designed to ease the newly arrived immigrant students into the public school 
environment in a supportive and non-threatening manner. The pre-beginner and newcomer subjects for this study were chosen directly from the newcomer and mainstream ESL programs.

\section{Subject Group}

As mentioned above, the following criteria were used to classify all study participants in both groups as "pre-beginners."

1. students had been in the United States for six months or less, 2. students scored a "2" or below on the IDEA Oral Language Proficiency Test, and 3. students had not previously attended school in the United States.

The 54 subject students ranged in age from six to 14 years. Although there were not equivalent numbers of students from each language within each group (newcomer and pre-beginner), the total number of study participants was fairly evenly distributed by language group, with approximately one third of the total group representing each of the three languages. The first language backgrounds of the students were Russian (30\%), Spanish (37\%), and Vietnamese (33\%). This choice of language groups was due to the large percentage of these language speakers enrolled in the Portland Public School System at the time of the study. Figure 2 illustrates the first language breakdown of the study participants $(\mathrm{N} / \mathrm{C}=$ Newcomer; $\mathrm{P} / \mathrm{B}=$ Pre-Beginner $)$. See Appendix $\mathrm{C}$ for a complete demographic breakdown of the study participants. 


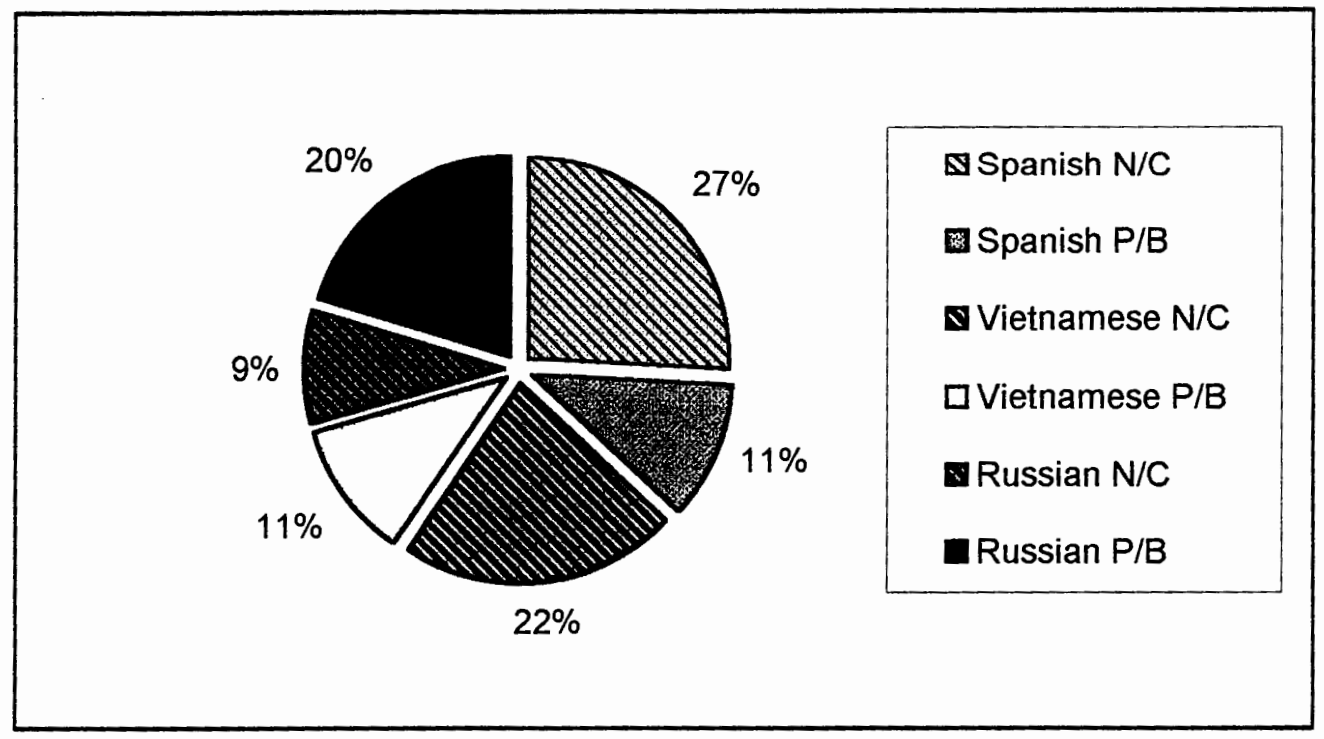

Figure 2. First language breakdown of study participants by group.

\section{Group A: Newcomer Program}

Group A consisted of 31 first through eighth grade students (with fourth grade as the median) from the Portland Public School's newcomer program which is currently administered at Carter Elementary School and Roslyn Middle School. Within the newcomer group, 14 (45\%) students were native Spanish speakers; $12(39 \%)$ students were native Vietnamese speakers; and $5(16 \%)$ students were native Russian speakers. These students received the newcomer program's curriculum of school orientation and adjustment as well as additional bilingual support. The students were in the newcomer program from the first six weeks of school until they were judged ready to exit and attend their mainstream ESL schools. All of the 31 Group A students used in this study successfully completed the newcomer curricula and were therefore exited from the newcomer program within the first six months of the school year. The study questionnaires were then answered by the students' new mainstream teachers after 
enrollment in their regularly assigned ESL schools. The intention of the questionnaires was to compare the social and school adjustment of these pre-beginner students who had completed the newcomer program to that of those who were directly mainstreamed without newcomer services.

\section{Newcomer Curriculum}

The curriculum of the newcomer center is designed to ease newly arrived immigrant students into the public school environment in an educationally sound and culturally supportive manner. In addition to a modified English curriculum, the students receive bilingual instruction, math instruction and an intensive orientation to the structure and expectations of the public school system. As often as possible, the newcomer students are mainstreamed into interactions with native English speakers at their host schools. This mainstreaming usually occurs during activities such as music, physical education, lunch and recess.

\section{ESL Curriculum}

Because the students have little to no English upon their arrival to the newcomer center, the English curriculum is basic. Emphasis is placed on simple and practical vocabulary such as school words (bathroom, scissors, principal, etc.), directions (line up, copy, draw, etc.), colors, numbers, days, months and weather. The vocabulary is most often introduced and practiced during structured lessons in the morning. Basic reading 
and writing skills are also stressed through whole language instruction ${ }^{1}$, daily success letters ${ }^{2}$, journal writing, and thematic teaching. Group and individual projects, as well as thematic activities are often worked on in the afternoon ESL sessions. Students are also given ample time in which they are encouraged to interact with one another in a less formal environment in order to encourage more spontaneous expressions and uses of the English language then occur in more structured classroom activities. This less structured time is often used by the students to play games with one another, complete projects and pursue individual interests.

The ESL curriculum is divided into two sessions: approximately one hour in the morning and one and one half hours in the afternoon. This ESL curriculum accounts for approximately $50 \%$ of the newcomer student's day.

\section{Native Language Literacy}

In addition to teaching English skills, native literacy is provided as often as possible to the newcomer students. The students are encouraged to read and write in their native languages with the expectation that strong native language literacy skills will transfer to their English acquisition. The larger language groups such as Russian, Spanish, and Vietnamese have daily native language literacy classes provided by bilingual assistants and/or bilingual teachers. When possible the smaller language groups such as

\footnotetext{
${ }^{1}$ Whole language is a teaching philosophy developed in the 1970's. This orientation focuses on the broad meaning of text when teaching reading and writing, rather than on the individual components such as spelling and vocabulary. For example, a class may read a book together. Using the common text the students will learn new vocabulary, write stories or reactions, retell the story, or create group projects that illustrate their experiences with the story.

${ }^{2}$ Each day the teacher or class chooses a letter from the alphabet for special emphasis. For example, if the letter "P" is chosen, the class will then generate a list of words that begin with the letter $\mathrm{P}$, discuss the sounds P makes, etc. The teacher will list these words on chart paper for future assignments such as copying into dictionaries, drawing pictures to match the words, or translations into native languages.
} 
Haitian, Oromo and Croatian also receive as much bilingual assistance as is available. Unfortunately, it is often difficult to find teachers with experience in these languages, or funding for their hiring. As a result, the smaller language groups may receive limited (one or two days each week) or no bilingual support whatsoever. On the days when these language groups do not have support available, they receive additional ESL support while native language literacy is scheduled.

As often as possible, native language literacy is taught by a native speaker of the language. When native speakers are not available, bilingual teachers with the target language as their second language are employed. Native language literacy is an opportunity for these newcomer students to work in their native languages in all areas of the curriculum. Often native literacy classes are taught around a theme in which the students have expressed particular interest. Native literacy time is also used for cultural orientation. School rules and procedures (for example bus, bathroom, playground and lunch rules) can be discussed in the native language with a group of language and cultural peers. This is often helpful when American norms and expectations differ from those of the students' home countries.

\section{Additional Subjects}

In addition to offering intensive English, native language literacy, and cultural orientation, the newcomer program provides exposure to math, physical education and music.

Math is generally taught on an individual basis by assigning the students to grade and/or ability level math books. Bilingual and ESL teachers are all involved in the math process by providing individual and small group instruction. 
Physical education and music are generally taught by district employees specializing in these subjects. Occasionally, when these services are not provided, the ESL teachers will incorporate these subjects into their ESL lessons.

The newcomer day is typically about two hours shorter than the average school day. This shortened schedule is due to difficulties in scheduling busses for the program. Because the newcomer center is a magnet program, it must bus students from all over the district. The busses serve multiple schools, and transportation must therefore be scheduled around the basic transit requirements of mainstream school schedules. For this reason, newcomer students are picked up after mainstream students are dropped off at school in the morning, and they must be taken home before mainstream students are excused. In addition to causing a shortened day for newcomer students, the limited availability of busses makes it impossible for students living in outlying areas of the city to attend the newcomer programs. These students are instead sent directly to their mainstream schools and are therefore qualified to participate in the pre-beginner Group B of this study. An example schedule for the typical newcomer day in the Portland program follows:

\section{Sample Newcomer Schedule}

8:30 Student busses arrive. Breakfast.

9:00 ESL Instruction

10:00 Native Language Literacy/Math

11:30 Lunch/Recess

12:00 ESL Instruction 
1:45 Load busses for home

Physical education and music are scheduled into weekly time slots which usually occur during the $\mathrm{ESL}$ instructional time.

Group B: Standard ESL Program

Group B consisted of 23 first through eighth grade students (with third grade as the median) in the Portland Public School System who met pre-beginner criteria, but were unable to attend the Newcomer Program due to transportation problems (see discussion above) or family refusal. The participating subjects included six (26\%) native Spanish speakers; six (26\%) native Vietnamese speakers; and 11 (48\%) native Russian speakers (refer back to Figure 3). The students in Group B were placed in mainstream classrooms throughout the Portland district. This group was exposed to standard grade level curriculum and had additional ESL support and occasional bilingual support provided to them throughout the week. Two basic models were employed within this group.

\section{Mainstream ESL Curriculum}

Students who are unable to attend the Newcomer Program are instead sent to their assigned ESL mainstream school. In all of these schools the pre-beginner students are placed within a mainstream class at their specific grade level. In this classroom, they are presented with the state mandated curricula for that grade level. Because of the various demands on most mainstream teachers, the pre-beginner students are likely to receive less consistent and less individualized support than their newcomer counterparts. The experiences these pre-beginner children have are as varied as their teachers, peers and schools. Most mainstream teachers try to incorporate pre-beginners into their 
classrooms. For example, in classrooms with bilingual children who speak the prebeginner's native language, the "buddy system" ${ }^{3}$ is often used to help the pre-beginner understand what is happening around her. Teachers who have experience with and interest in these ESL students find many exciting and creative ways to incorporate these new students into their classrooms and modify the curriculum to the students' ability level.

In addition to spending time in their mainstream classroom, these students are provided with additional ESL support. In the Portland district, this support usually comes in several different forms including pull-out, bilingual assistance, team teaching, or a combination of all of these, as discussed below.

In the Portland Public School district, pull-out programs are the most commonly employed ESL teaching methods. In a pull-out program, the ESL students are removed from their mainstream classrooms and sent to the ESL classroom for special help during the day. The amount of time that these students spend in the ESL room varies with the amount of assistance the student needs. Advanced students who need minimal help may come to the ESL class once a week for 30 minutes, whereas a pre-beginner may spend several hours a day with the ESL teacher. The individual schedules are determined by the ESL and mainstream teachers based upon the student's language and academic abilities. Where bilingual assistance is available, a bilingual teacher may pull the student out of their mainstream class for tutoring, or actually sit in class with the student to

\footnotetext{
${ }^{3}$ The "buddy system" is a process in which students needing additional assistance are paired with academically successful students (from the new students' native language group if possible) who can assist the pre-beginner in understanding assignments, routines, and the general expectations of the class.
} 
provide assistance with explanations and class work.

A relatively new model in the Portland Public School District is the team teaching approach. In this model, an ESL teacher goes into the mainstream classroom and works with the mainstream teacher to plan lessons, modify curriculum and teach students. In this model, the ESL student never has to leave the classroom and therefore does not miss any mainstream instruction.

In both of these models, the ESL teachers and bilingual assistants work closely with the mainstream teacher in an effort to coordinate curriculum and instruction.

\section{Procedure}

Human subject consent forms regarding participation in this study were translated by Portland Public School employees serving as educational assistants in the newcomer program. Translations were provided in the home languages of the students: Russian, Spanish and Vietnamese (see Appendix D). In all three cases, the translations were reviewed and edited by at least one other person bilingual in both English and the language in question. In some cases (particularly Russian), some of the wording was altered to suggest a less formal style than the original wording of the consent form produced by the Human Subjects Committee. The intent of this de-formalization was that study participation would possibly be higher if the study was not perceived as a government or district related experiment. A second consent form was also designed for the teacher who would be filling out the questionnaires (see Appendix D). The teacher consent forms were written in English.

Packets consisting of a cover letter, the consent forms and the questionnaires were handed out during a monthly ESL meeting in which all district ESL teachers were 
in attendance. The researcher preceded this distribution with a brief explanation of the study and instructions for the return of the materials. Materials were to be sent by PONY (inter-district mail) or picked up by the researcher upon their completion. Parent and student questions about the project were answered by bilingual employees of the Portland Public School System and/or the researcher.

All of the subjects entered school within the first sixty days of the beginning of the 1994-95 school year. Group A entered the Newcomer Program at Carter Elementary School or Roslyn Middle School, where they remained until exited to their assigned mainstream school. Among the Group A subject students, the time enrolled in the newcomer program ranged from 10 to 18 weeks. The questionnaires for Group A were then sent to the student's new teacher after the student had six or more weeks to adjust to their new mainstream environment.

The participants in Group B were assigned directly to their mainstream school in which they remained the entire school year. The questionnaires for Group B were filled out by their respective mainstream teachers, to whom the pre-beginners had been assigned since the beginning of the school year.

Both groups were examined on their school and social adjustment six months after entering the school system. The examination was conducted using a teacher questionnaire (Appendix E) which was filled out by the student's mainstream classroom teacher. ESL teachers at each site acted as liaisons between the classroom teachers, parents, students and the researcher. Questionnaires were passed out to teachers in March 1995, six months after the beginning of school. The questionnaires were returned by the end of April 1995. Return rate will be discussed in Chapter IV. 


\section{Questionnaire Design}

The questionnaire was designed using three primary models including Project GOAL exit criteria, follow-up questionnaires and pre- and post-program evaluations (see Appendix E for examples of these) as models. As described in Chapter II, Project GOAL was designed in 1986 to provide Portland public school children who met prebeginner criteria with 1) extensive ESL instruction; 2) native language literacy; and 3) orientation to school and American life. The exit criteria, follow-up questionnaires and pre- and post-program evaluations used by Project GOAL were designed in accordance with a Title VII grant from the U.S. Office of Education, Office of Bilingual Education and Minority Language Affairs (OBEMLA). These specific exit criteria and program evaluation questions were based upon the Project Goal objectives (see Appendix F) which were in turn based in part upon the Salem-Keizer Newcomer Center in Salem, Oregon.

The 51 questions selected for this survey were divided into four sub-sections: 1) academic; 2) behavior; 3 ) interpersonal relations; and 4) knowledge of school routine and rules. Example questions from the study questionnaire include questions number 1) Pays attention to the instructor (academic); 22) Does not crowd in line (behavior); 32) Initiates interactions with others (interpersonal relations); and 43) Explains absences due to medical, or other necessities (knowledge of school routine and rules). Teachers were asked to answer each question using a Likert scale with a range of 0 through 4. The scale for scoring was as follows: $0=$ never; $1=$ seldom; $2=$ some of the time; $3=$ most of the time; and $4=$ all of the time. Teachers were encouraged to comment on any area of particular concern to them, with close attention to special measures taken 
and difficulties encountered by having newcomer/pre-beginner students in their classrooms.

\section{Pilot Testing}

In order to test the general quality of the survey questions, rough drafts of the questionnaire were initially given to several newcomer teachers at Carter Elementary School. The teachers were asked to choose two students of varying ability levels on which to fill out the sample questionnaires. The teachers were encouraged to comment on any difficulties they had in answering the questions and all responded that they enjoyed filling out the questionnaires and did not claim to have any questions or problems. Based on the positive preliminary responses, the questionnaires were not altered before being sent out to the final study participants.

\section{Means of Analysis}

The aim of this study was to use a teacher questionnaire to determine if any statistically significant differences existed between the group of students who went through the newcomer program and those students who were directly mainstreamed in relation to their social and school adjustment. Once the questionnaires were returned from the participating schools, the teachers' responses were compiled and taken to the Portland State University Statistics Lab for analysis. The data were analyzed in such a way as to compare group responses to each individual question as well as group responses to the broader categories to which each question belonged. The purpose of the statistical analysis was to determine possible statistically significant differences between the two groups. The differences between the two groups were measured using a two sample $t$-test. The $t$-test is a statistical measure designed to determine the 
probability that two means may or may not have been drawn from the same population. The test compares the two groups with the underlying assumption that there will be no difference. If the results of the comparison show a value below the significance level set by the researcher (in this case $\mathfrak{p}<.05$ ), then the differences can be considered statistically significant and the groups significantly different from one another. The $t$-test, known as a parametric measure, is a powerful statistical measure that requires a strict normal distribution in the samples measured. Due to the small sample size of the study, parametric as well as non-parametric statistical measures were used in order to assure accuracy. The non-parametric measure used in this study was the Mann Whitney $U$ test. Non-parametric tests are considered less powerful than parametric tests. However, because both the parametric and non-parametric measures showed similar results, the sample size was assumed to have no effect on the outcomes.

In addition to the original hypothesis posed by this study, differences according to gender, age and language were also analyzed. A two sample $t$-test and the Mann Whitney $U$ test were also used to analyze possible differences that might occur in the responses between males and females. Because the $t$-test is designed to measure differences between two groups only, a 1-Way ANOVA (parametric) and the KruskalWallis (non-parametric) were used to analyze possible differences by age and language group. Statistical significance was set at a .05 alpha level $(\mathrm{p}<.05)$ for all tests. 


\section{CHAPTER IV}

\section{RESULTS}

This study employed a questionnaire which was designed to determine if differences exist between two groups of newly arrived immigrant students in the Portland Public School District. The questionnaire responses were analyzed using four statistical measures, two parametric, and two non-parametric. The results of this study, including response rate, data analysis and statistical results will be included in this chapter. In addition, several unanticipated findings will be presented as well.

\section{RETURN RATE}

As mentioned in Chapter III, the questionnaires were filled out by students' mainstream classroom teachers. Ninety questionnaires were sent out to teachers in March of 1995. Three pieces of information were required to be returned to the researcher in order to be used in the study: the questionnaire, the teacher consent form and the family consent form. Of the 90 questionnaires sent out, $54(60 \%)$ were returned with all three necessary pieces. There was a $67 \%$ (31 questionnaires) return rate among the newcomer group (Group A) and a $52 \%$ (23 questionnaires) return rate among the mainstream group (Group B). Of the 36 questionnaires not returned, 13 (36\%) of the students had moved out of district; $12(33 \%)$ teachers refused participation; nine (25\%) families refused participation; and two (5\%) students were excused from the study to avoid possible skewing of the data. Of these two students, one was excused because she 
was participating in a bilingual school and was therefore not directly mainstreamed into the traditional school setting, and the second student was excused because she was adopted by an American mono-lingual family. Please see Table IV for a breakdown of the questionnaire returns.

TABLE IV

QUESTIONNAIRE RETURN RATE

\begin{tabular}{|c|c|c|c|c|c|c|}
\hline RETURN RATE: & \multicolumn{3}{|c|}{ Group A: Newcomer } & \multicolumn{3}{|c|}{ Group B: Pre-Beginner } \\
\cline { 2 - 7 } & $\begin{array}{c}\text { \# sent } \\
\text { out }\end{array}$ & $\begin{array}{c}\# \\
\text { returned }\end{array}$ & $\begin{array}{c}\% \\
\text { returned }\end{array}$ & $\begin{array}{c}\text { \# sent } \\
\text { out }\end{array}$ & $\begin{array}{c}\# \\
\text { returned }\end{array}$ & $\begin{array}{c}\% \\
\text { returned }\end{array}$ \\
\hline \hline Spanish Speakers & 15 & 14 & $93 \%$ & 15 & 6 & $40 \%$ \\
\hline Russian Speakers & 16 & 5 & $31 \%$ & 20 & 11 & $55 \%$ \\
\hline $\begin{array}{c}\text { Vietnamese } \\
\text { Speakers }\end{array}$ & 15 & 12 & $80 \%$ & 9 & 6 & $66 \%$ \\
\hline
\end{tabular}

Overall return rate among the language groups varied widely. The Vietnamese speakers produced the highest rate of return with a $75 \%$ return rate. Spanish speakers had a $66 \%$ return rate and Russian speakers had a $44 \%$ rate of questionnaire return.

\section{SUMMARY OF FINDINGS}

The main purpose of this study was to determine if a significant positive correlation existed between success in school and social adaptation and attendance in a newcomer program. As the study developed, its scope was broadened to include gender, age and native language. The questions asked by this study were: (a) Are there significant differences between students who have attended a newcomer program and students who have been directly mainstreamed with respect to social and school adaptation? (b) Are there significant differences between males and females with respect 
to social and school adaptation? (c) Are there significant differences between age groups with respect to social and school adaptation: (d) Are there significant differences between language groups with respect to social and school adaptation?

Because the main purpose of this study was to determine the social and school success of students exiting Portland's newcomer program as compared to students who were directly mainstreamed, the questions for this questionnaire were drawn from early goals and evaluations designed for the newcomer program when it first began. Many of these questions were divided into descriptive groups at that time, and these groups have been utilized again for the purposes of this study. The following description of the results will parallel these descriptive groups as follows: questions 1-14 (academic); questions 15-28 (behavior); questions 29-37 (interpersonal) and questions 38-51 (school routine).

The first statistical analysis conducted compared those students who had completed the newcomer program to those students who had been directly mainstreamed. These two groups were compared using a two sample t-test and the Mann Whitney $\mathrm{U}$ as parametric and non-parametric methods of statistical analysis. Neither of these two statistical tests showed any significant difference in response to any of the questions. In order to further clarify the findings, the mean response for each question by each group was analyzed as well. This was done in order to determine possible trends in responses. Figures 4,5,6 and 7 illustrate the mean score comparison between the two groups. The numerical data from the mean scores can be found in Table V. 
TABLE V

MEAN RESPONSES BY GROUP

\begin{tabular}{|c|c|c|c|c|c|}
\hline Question & Newcomer Group A & Pre-Beginner Group B & Question & Newcomer Group A & Pre-Beginner Group B \\
\hline 1 & 3 & 2.82 & 28 & 3.22 & 3.36 \\
\hline 2 & 3.06 & 3 & 29 & 1.83 & 2.08 \\
\hline 3 & 2.87 & 2.9 & 30 & 3.16 & 3.42 \\
\hline 4 & 3.13 & 3.18 & 31 & 2.96 & 3.04 \\
\hline 5 & 3.12 & 3.18 & 32 & 2.12 & 2.39 \\
\hline 6 & 2.93 & 3 & 33 & 2.96 & 2.69 \\
\hline 7 & 3.12 & 3.22 & 34 & 3.19 & 3.13 \\
\hline 8 & 3.48 & 3.43 & 35 & 3.26 & 3.52 \\
\hline 9 & 3.35 & 3.3 & 36 & 2.06 & 2.21 \\
\hline 10 & 3.61 & 3.56 & 37 & 3 & 3.04 \\
\hline 11 & 3.45 & 3.52 & 38 & 3.23 & 3.39 \\
\hline 12 & 3.45 & 3.45 & $\overline{39}$ & 3.63 & 3.56 \\
\hline 13 & 2.93 & 3.04 & 40 & 3.66 & 3.59 \\
\hline$\overline{14}$ & 2.09 & 2.08 & 41 & 3.74 & 3.73 \\
\hline 15 & 3.51 & 3.6 & 42 & 3.42 & 3.68 \\
\hline 16 & 3.35 & 3.56 & $\overline{43}$ & 2.8 & 3.21 \\
\hline 17 & 3.38 & 3.56 & 44 & 3.48 & 3.54 \\
\hline 18 & 3.37 & 3 & 45 & 3.44 & 3.57 \\
\hline 19 & 2.9 & 2.95 & 46 & 3.48 & 3.6 \\
\hline 20 & 3.28 & 3.17 & 47 & 3.58 & 3.65 \\
\hline 21 & 3.58 & 3.6 & 48 & 3.55 & 3.56 \\
\hline 22 & 3.12 & 3.4 & 49 & 3.66 & 3.8 \\
\hline 23 & 3.38 & 3.73 & 50 & 3.62 & 3.68 \\
\hline 24 & 3.41 & 3.69 & 51 & 3.58 & 3.72 \\
\hline 25 & 2.93 & 3.27 & & & \\
\hline 26 & 3.55 & 3.66 & & & \\
\hline 27 & 3.25 & 3.57 & & & \\
\hline
\end{tabular}


The mean responses by comparison groups A and B are presented in Figures 3,4,5 and 6. From Figure 3 we can see that the patterns of Group A and Group B responses are similar for questions $1-14$, those dealing with academic achievement.

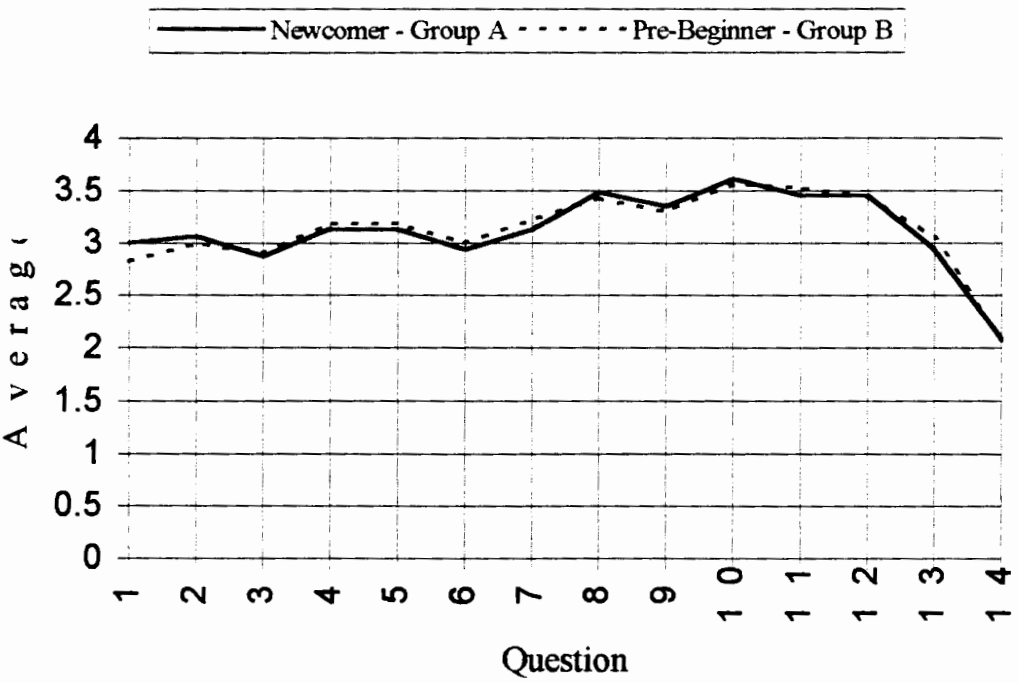

Figure 3. Mean responses for questions $1-14$.

There appears to be no noticeable difference in teacher opinions of academic success between those students who attended the newcomer program and those who did not. As mentioned above, the statistical analyses bear this out.

Similar results occur with the rest of the questions in this section as well. As with the previous questionnaire section dealing with academics, questions $15-28$ measuring behavior, showed similar results (Figure 4). 


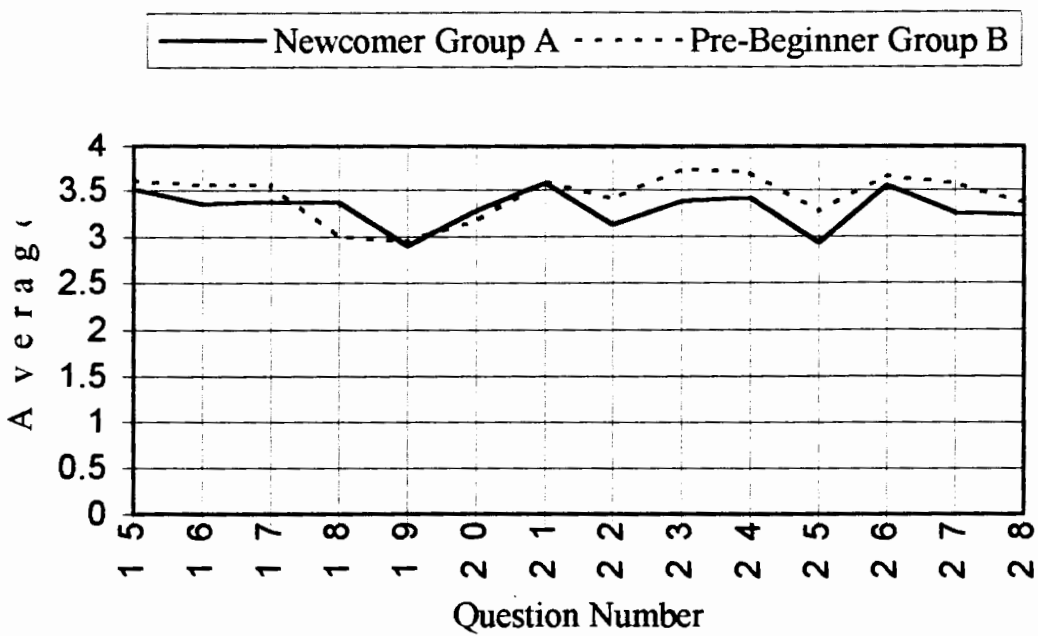

Figure 4. Mean responses for questions $15-28$.

As with the previous section, teachers scored the two comparison groups similarly. However, unlike the section on academics, Figure 4 shows a slight divergence in the scores. Although the two groups follow the same pattern, it appears that with the exception of questions 18 (Awaits turn to speak or act) and 20 (Refrains from disruption of class or class activities) the pre-beginner Group B was scored slightly higher than the newcomer Group A.

This trend continues with questions 29 - 37 (Interpersonal Relations). As Figure 5 illustrates, the pre-beginner Group B scores slightly higher in this category as well. 


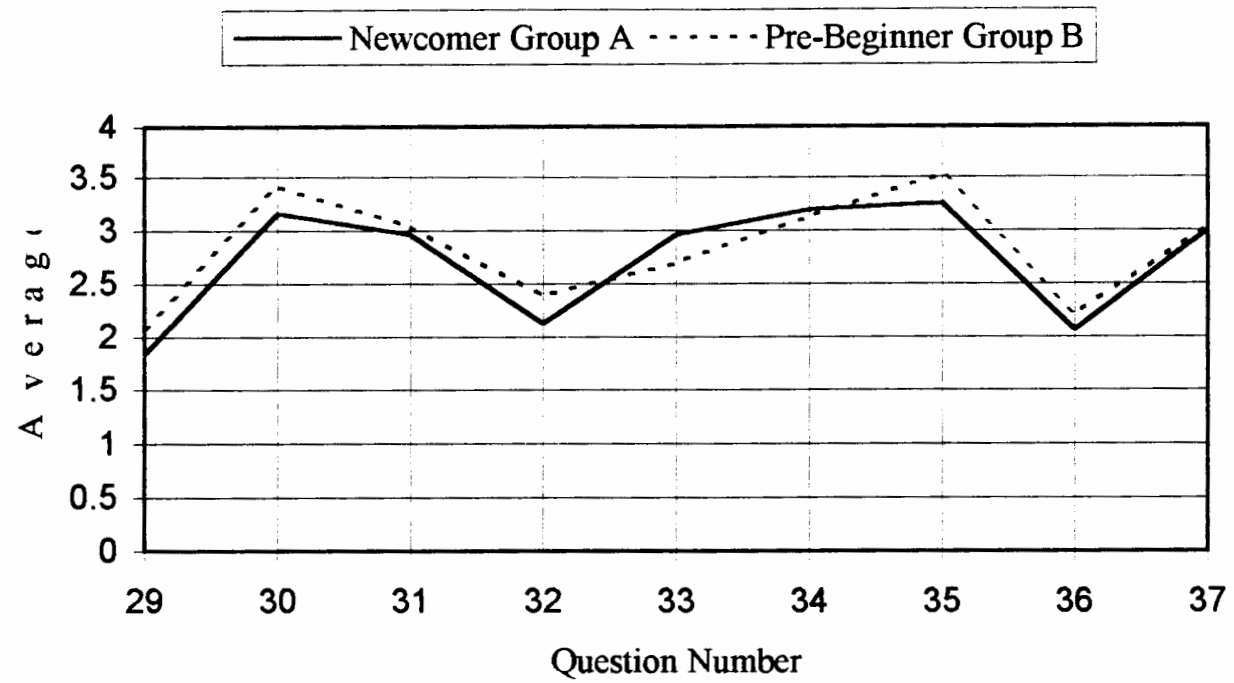

Figure 5. Mean responses for questions $29-37$.

The exceptions to this trend appear to be questions 33 (Forms friendships) and 34 (Is comfortable in presence of instructor) in which the newcomer Group A scores slightly higher.

The final section (Figure 6), questions 38 - 51 (Knowledge of School Routine), brings the two comparison groups back to the parallel pattern seen in the first section (Academic, questions 1 - 14). 


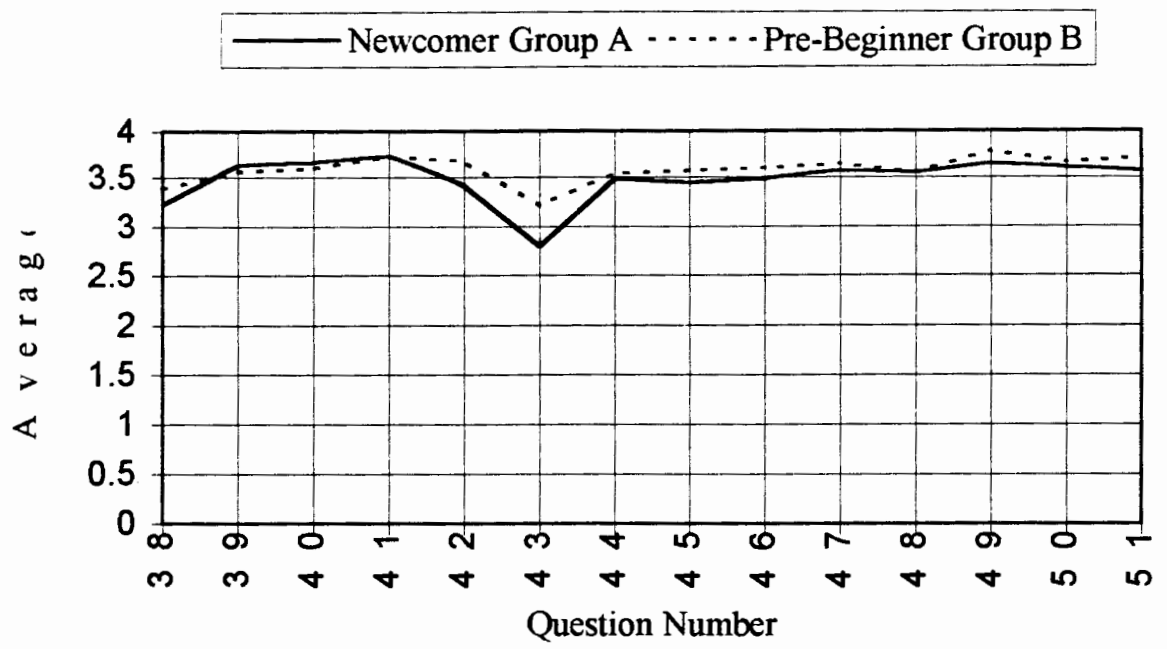

Figure 6. Mean responses for questions $38-51$.

Although not as obviously parallel as the first section, the two groups do follow a similar pattern including a noticeable dip in question 43 (Explains absences due to medical, or other necessities). Questions 38 (Follows classroom rules), 42 (Stays home when ill), 45 (Demonstrates appropriate behavior during earthquake drills), 46 (Demonstrates appropriate behavior for assemblies), 49 (Follows procedures for attaining lunch tickets) and 51 (Demonstrates appropriate care of books) once again show a slightly higher score for the pre-beginner Group B group.

As mentioned earlier, neither the two sample $t$-test nor the Mann Whitney $\mathrm{U}$ showed any significant difference in response to any of the questions. Thus, it would appear that students exiting from the newcomer program are at no more of an advantage or disadvantage than students who are directly mainstreamed into their regularly assigned school. 


\section{ADDITIONAL FINDINGS}

In addition to contrasting the two study groups, comparisons were also made between males and females, age groups and language groups. Some unexpected, yet interesting findings emerged from these comparisons.

\section{Differences Between Males and Females}

Again, a two sample t-test and the Mann Whitney $U$ were used as the parametric and non parametric measures. Of the 51 questions on the questionnaire, girls were scored significantly higher than boys on 39 of the questions as well as on the overall general classifications of "academic," "behavior," "interpersonal skills," and "knowledge of school routine/rules." As can be seen in Figure 7, girls were scored higher than boys in all but question 14 (Approaching grade level performance) of the first 14 questions.

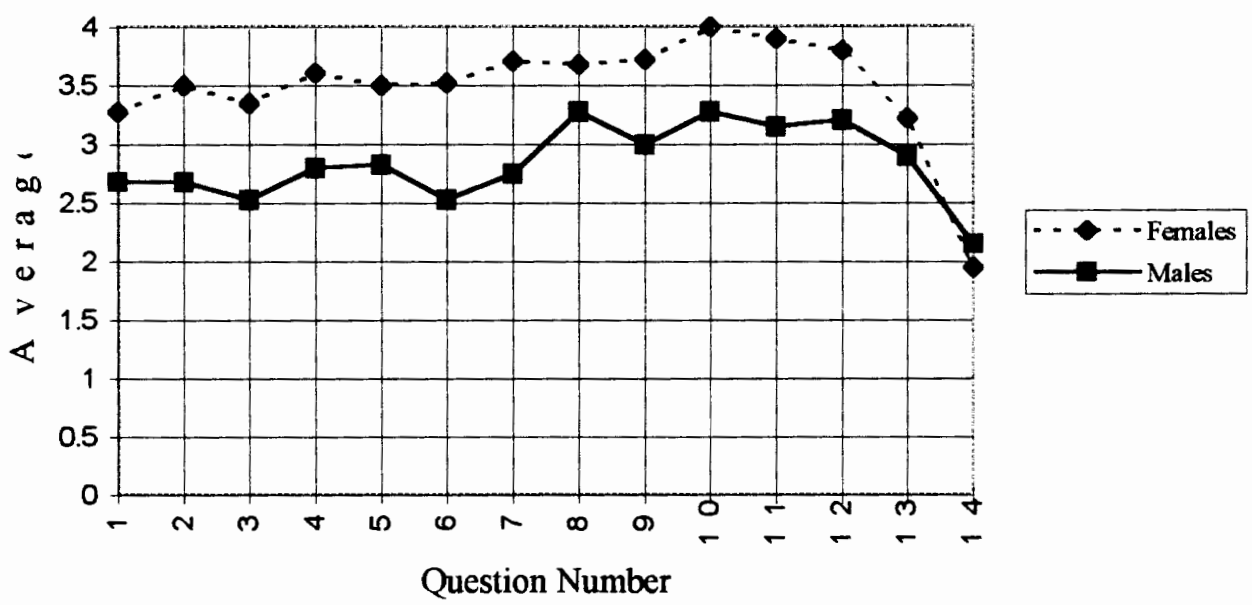

Figure 7. Mean responses for males and females for questions $1-14$.

Of the 14 questions in the "academic" section of the questionnaire, only questions 13 (Demonstrates progress in English) and 14 (Approaching grade level performance) did not prove significantly different. Although question 8 (Demonstrates understanding of 
time) was shown to be significant by the $t$-test, it was not shown significant by the Mann Whitney $U$. Therefore, the conclusiveness of the possible significance of question 8 is unknown and not considered with the other significant scores of this study.

As can be seen in Figure 8, girls were again scored higher than boys in the "behavior" section of the questionnaire.

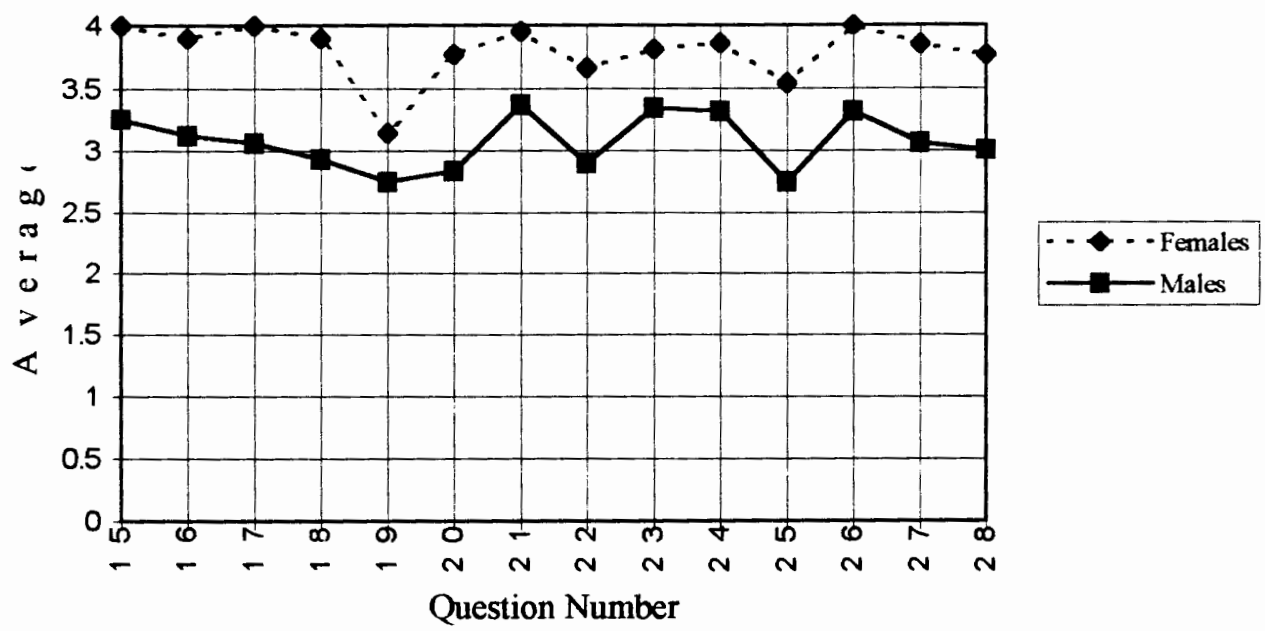

Figure 8. Mean responses for males and females for questions $15-28$.

According to the statistical measures used in this comparison, all but question 19 (Tries to participate in all activities) were found to show girls scoring significantly higher than boys.

Although females were again scored significantly higher than males in the overall section of "interpersonal skills", there were five questions within this section that did not prove to be significant: 29 (Mixes with a variety of student groups); 31 (Responds appropriately to others); 32 (Initiates interactions with others); 33 (Forms friendships) and 36 (Has made friends outside of his/her own language group). As can be seen in 
Figure 9, the mean score for females actually drops below that of the males for question 32.

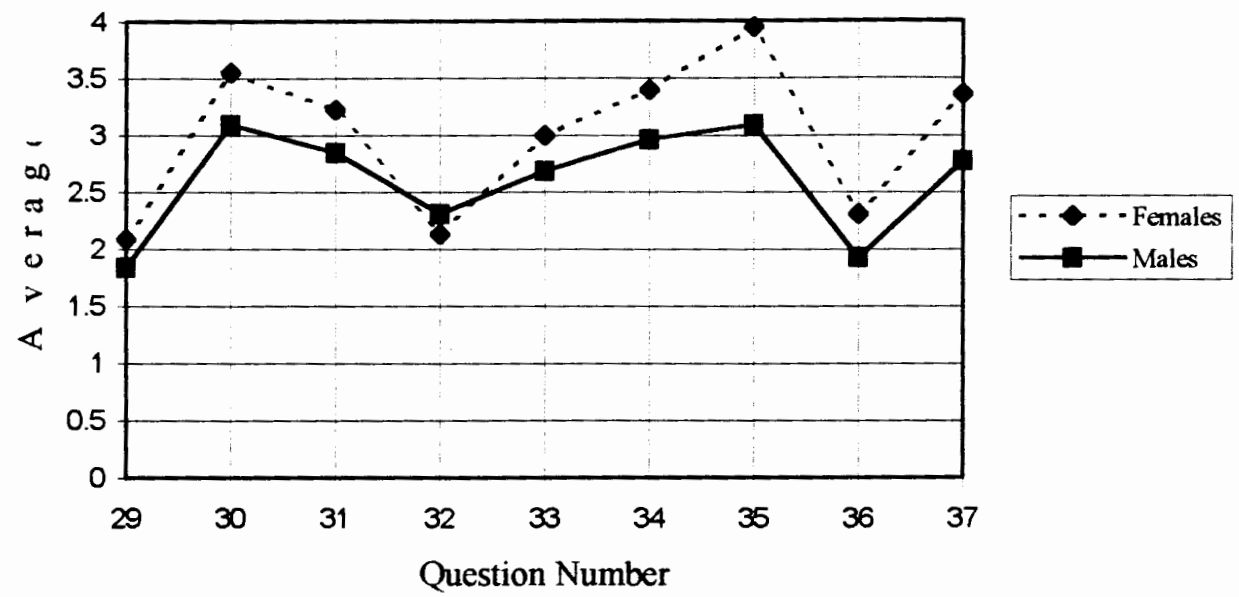

Figure 9. Mean responses for males and females on questions $29-37$.

For all other questions in this section however, the females are scored noticeably higher.

The final section of the questionnaire (Figure 10), "knowledge of school routine/rules," shows a similar pattern. Again, the girls are scored significantly higher than the boys in the overall general category as well as on most of the questions in the section. Question 43 (Explains absences due to medical, or other necessities) shows a noticeable dip in scores for girls, and question $47^{1}$ (Has satisfactory attendance) shows a particularly close score for boys and girls. Neither of these questions nor question 42 (Stays home when ill) showed any significant difference between males and females. Further discussion of all of the above results will take place in Chapter $\mathrm{V}$.

\footnotetext{
${ }^{1}$ For question 47 , females had a mean score of 3.59 whereas males had a higher mean score of 3.62 .
} 


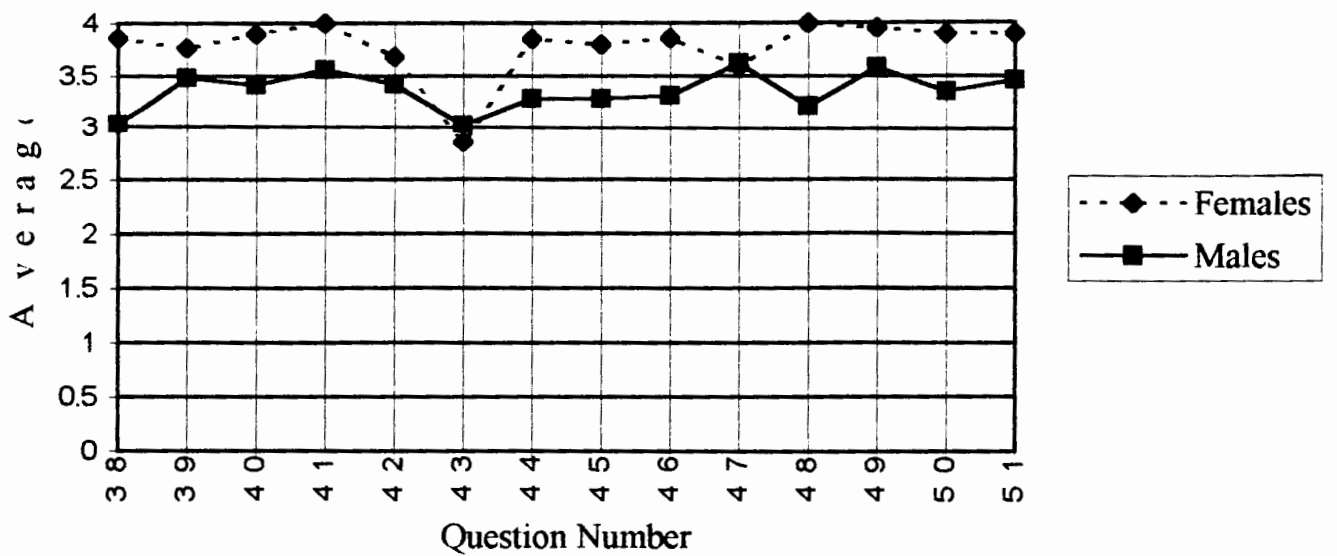

Figure 10. Mean responses for males and females on questions $38-51$.

\section{Differences Between Age Groups}

Because children experience a great deal of social growth and maturation during the first years of school, the subjects were sub-categorized into one of three age groups in order to determine if age was a factor in this study. The classifications were as follows: early elementary - first through third grades (1 - 3); upper elementary - fourth and fifth grades (4 - 5); and middle school - sixth through eighth grades (6 - 8). Because three groups rather than two were to be measured in this comparison, the $t$-test and Mann Whitney U test could not be used. Instead, a 1-Way ANOVA was used as the parametric statistical measure, and the Kruskal-Wallis was used as the non parametric statistical measure. For most questions the conclusions from both tests were in agreement, with only questions 19 (Tries to participate in all activities) and 43 (Explains absences due to medical, or other necessities) showing statistically significant differences among the three age groups. See Figure 11 for an illustration of these results. 


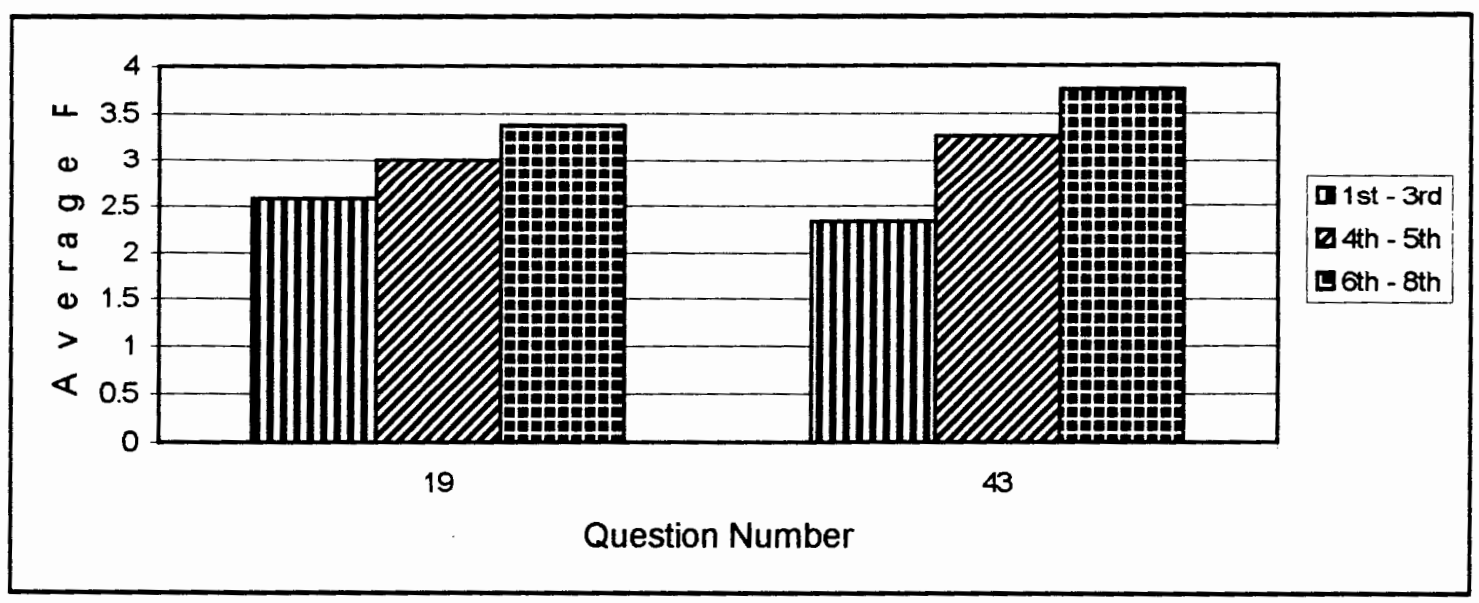

Figure 11: Mean responses to questions 19 and 43 by age group.

The first of these, question 19 (Tries to participate in all activities) shows the youngest students $\left(1^{\text {st }}-3^{\text {rd }}\right.$ graders $)$ received a mean score of 2.58 . This group scored significantly lower than the middle school students (mean score 3.38). The fourth and fifth graders scored in the middle (mean score of 3 ), however there was no significant difference in their score.

The other question showing significance by age group is number 43 Explains absences due to medical, or other necessities). Like the previous question, the $1^{\text {st }}-3^{\text {rd }}$ graders had the lowest score (mean of 2.33). In this instance however, the young group scored significantly lower than both older groups, the $4^{\text {th }}-5^{\text {th }}$ graders having a mean score of 3.26 and the $6^{\text {th }}-8^{\text {th }}$ graders having a mean score of 3.75 .

Differences by Language Group

The 1-Way ANOVA and the Kruskal-Wallis were again used to look at possible differences by language group. The subjects for this study each fell into one of three language groups: Spanish, Vietnamese or Russian. Three of the test questions showed a 
significant difference according to both of these tests. In all three examples, the Russian and Spanish speaking students scored significantly different from the Vietnamese speakers. Figure 12 illustrates these results.

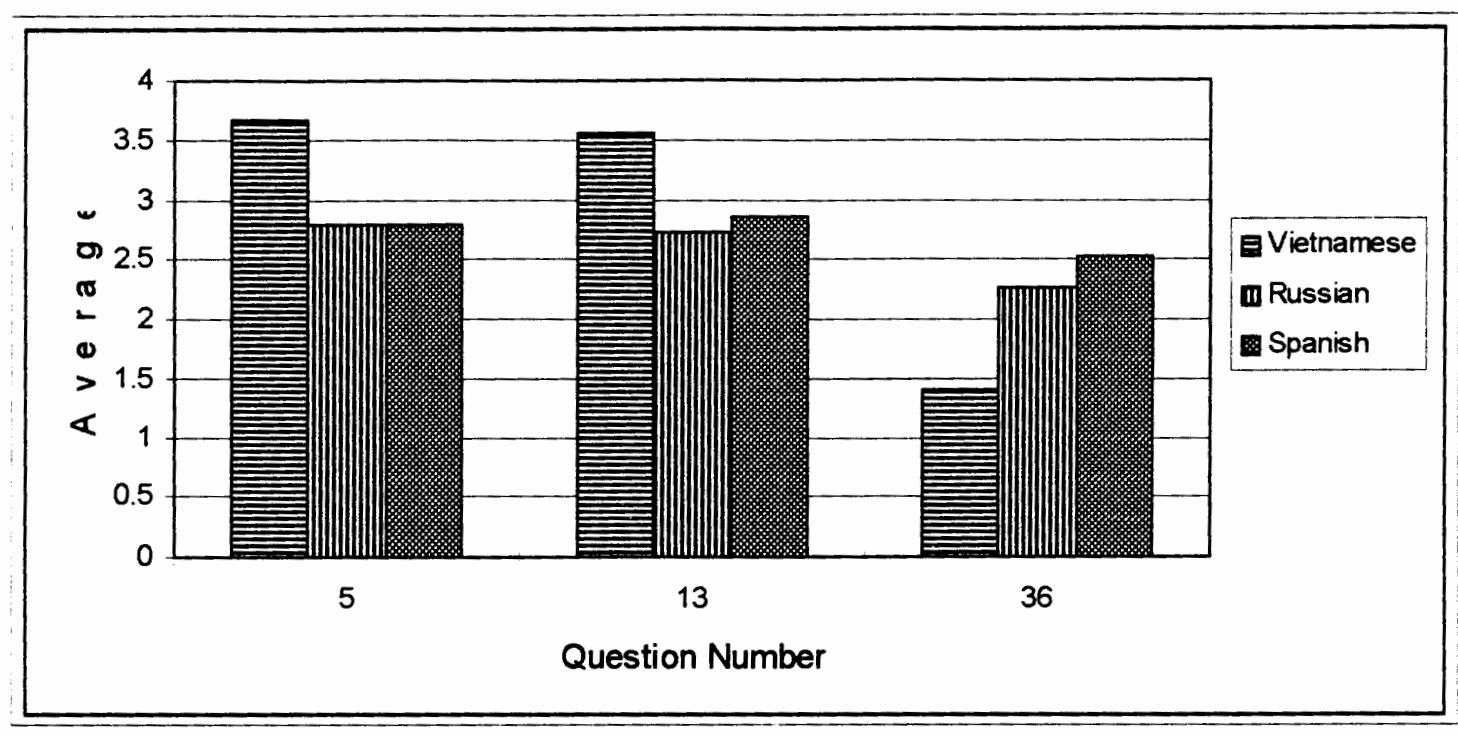

Figure 12. Mean responses for questions 5,13 and 36 by language group.

For the first of these questions, number 5 (Completes academic tasks to the best of personal ability), the Vietnamese speakers (mean score of 3.66) scored significantly higher than both the Russian speakers (mean score of 2.8) and the Spanish speakers (mean score of 2.8). This was true of question 13 (Demonstrates progress in English) as well. For question 13, the Vietnamese speakers had a mean score of 3.55 , whereas the Russian speakers had a mean score of 2.73 and the Spanish speakers had a mean score of 2.85 .

Interestingly, the opposite pattern develops in question 36 (Has made friends outside of his/her language group). For this question, the Vietnamese speakers (mean 
score of 1.41 ) scored significantly lower than the Russian (mean score of 2.26) and Spanish (mean score of 2.52) speakers. 


\section{CHAPTER V \\ DISCUSSION AND IMPLICATIONS}

Introduction

The purpose of this study was to determine if a positive correlation exists between participation in the Portland Public School's Newcomer Program and social and school adaptation of newly arrived immigrant children. It was hoped that a quantitative assessment of such a program could add to the large body of qualitative data collected in this area and ultimately contribute to the current discussions on ESL and bilingual program models. All statistical measures used in this study were in agreement in showing no significant differences in response to any of the questions as analyzed by study group. This result indicates that in the area of social and school adjustment, there may be no measurable advantage for students participating in the newcomer program relative to those students who are directly mainstreamed into a standard ESL program. However, due to the subjective nature of the topic, as well as several weaknesses in the study, there are alternative explanations for the lack of statistically significant differences. A discussion of the difficulties incurred in such research, as well as possible explanations for the study outcomes will be considered in this chapter. In addition, implications for the teaching of ESL and possible topics for future study will be included. 


\section{DISCUSSION}

One probable explanation for the lack of statistical difference between groups in the outcome of this study is related to the subjects' time of entry into the school system. All of the students used in this study entered the Portland Public School System within the first 60 days of the school year. Group A entered the newcomer program and Group B entered their assigned mainstream classrooms. When the students in Group A met the newcomer exit criteria (see Appendix G), they were then graduated on to their assigned mainstream classrooms. It was the teachers in these mainstream classrooms that were asked to fill out the questionnaires. Although all students participating in the study had been attending school for six months, the actual time they had been in the mainstream class varied from six months for those in Group B, to as little as six weeks for some of those in Group A. This variation in time could have had a meaningful effect on the statistical outcomes of the study.

\section{Classroom Dynamics}

In discussions with classroom teachers and principals, it seems clear that most of them consider the beginning of the year to be an important time for the establishment of rules, routines, friendships and the general development of a cohesive classroom dynamic. Teachers use this time to learn the strengths of their students and to develop goals and objectives for the class and for each individual. Although many of the children may already know each other or the teacher from previous years, children often behave and perform differently under different types of supervision and around different peer groups. Therefore, the beginning of a new school year puts all participants on an 
equal footing. Students form friendships with each other and a working relationship with their teachers at this time. Children who enter at the beginning of the year are part of this process, and as such become an important part of the classroom operations.

Also, the relationships that the teachers form with the students may be different with students who enter at the beginning of the year versus students who enter later in the year. During the course of this study, several educators agreed that teachers may have a more vested interest in students who have been in their class for the entire year. Not only have the teachers gotten to know the abilities and needs of the students better, but they have also witnessed academic growth in the students over a longer period of time. I myself have been called by mainstream teachers on numerous occasions after I have exited newcomer children into their classrooms. These teachers will comment that they believe the students have been exited into the mainstream too early and are concerned that the students "can't do anything". For example, one of the study participants who filled out a questionnaire on a recently exited newcomer student made this comment:

I know very little of the [newcomer] program - But students do not seem to have enough English skills when they enter my class to participate at grade level.

Unfortunately, these teachers may have an unrealistically high set of expectations for the English levels of these students who, upon entering the mainstream classroom, will more likely than not have academic difficulties for several years to come. In all cases, these students were performing at a high level in the newcomer classroom. Once the new teachers had adjusted their expectations, and once the newcomer students had had time 
to adjust to their new surroundings, the newcomer students were observed to perform more effectively. This is in great contrast to comments made by the teachers of the prebeginner Group B. Two participating mainstream teachers wrote of their experiences with newcomer level students who had not attended the newcomer program: has progressed so much since the fall! When I first started with him, he didn't speak at school, could barely write or draw, was never on task (although quiet), and seemed really lost in the ozone a lot. Now he speaks quite a bit of English, and he's become rather social. He knows his letters and letter sounds and is beginning to write his own stories in his journal!

It is much easier now to include ------ more effectively because he knows what is expected. He understands the language pretty well and so there's much less taking him by the hand and putting him through the motions like I used to have to do.

Because these teachers had the opportunity to observe the growth in the students, skills such as speaking "quite a bit in English", knowing "his letters and letter sounds", and understanding "the language pretty well", are considered successful, and indicate the advantage to a pre-beginner student of early-year entrance into a mainstream program.

\section{Adjustment to New Classroom}

In contrast, students who enter into an already established classroom mid-year may face adjustment problems. Not only do new students enter into an already established routine and curriculum of which they have no knowledge and had no part developing, but in order to form friendships they must break into already established friendship circles. If the new students are coming from another school program such as the newcomer program, they may be sad or depressed at leaving their friends, teachers and comfortable routines. In addition, the student may have a drop in self-confidence 
when faced with the challenge of unmodified grade level work. The stressful condition of entering a program midyear can result in children withdrawing, acting out or backsliding in their academics. These behaviors can make it difficult for teachers to develop a good understanding of the child for the first few months. And, although midyear entry is difficult with any student, it can be even harder with LEP students. Not only do these students lack knowledge of the specific established routines, but the teacher must often modify curriculum for them as well. With newcomer students in particular the challenge is greater. Many newcomer students have never attended school in the United States or in their native countries and must often be literally "walked through" the day's activities. As mentioned above, this seems to be less taxing on classroom teachers at the beginning of the year since the routine is not yet established with any of the students and the newcomer can be taught simultaneously with the rest of the class. Additionally, mainstream teachers may be less willing and have less ability to spend equivalent time introducing a midyear student to the class routine and environment. There are, however, special measures that the participating teachers in this study have successfully employed with pre-beginner/newcomer students. These suggestions include modifying work for the newcomer student, assigning a buddy to help with questions and difficult work, using the students' first language when bilingual help is available, whole-language and phonetics instruction, after school help, visual aids, allowing students to write in their first language, having translated letters sent home to parents, using volunteers to work one-on-one with the students, and using manipulatives. All of these measures can serve to ease the transition from the newcomer program to the 
mainstream classroom. In addition to the above methods, several of the participating

teachers also suggested a more gradual transition into the new school:

I think some come out [of newcomer] too early. Maybe a slow entry program would be better: Friday visits for two weeks or half days for one week. This way they could communicate their fears and/or problems to the newcomer teacher. Then problems could be dealt with swiftly.

Would like to see a meeting with parents of newcomers being mainstreamed, and new classroom teacher prior to admission. I believe it would be a nice way to start a cooperative relationship.

Furthermore, teachers who have worked with students with and without

newcomer experience claim to see value in the program:

The students that entered my class were brand new to this country and had never been to school, had no English language skills, and not a lot of appropriate social skills and they were totally overwhelmed and not prepared for their "school experience" in America. Students and their families that have been here awhile or through the Newcomer Program or even attended Kindergarten are much happier, better adjusted, and have an easier transition into this culture and its formal schooling structure.

In addition, teachers who have had the opportunity to see students before and after participation in the newcomer program are more likely to notice growth in the students.

For example, one mainstream ESL teacher related this story:

I sent two girls to newcomer and when I got them back they were socially different people: straight backs and confident. We were spending all our time with them at the expense of others - so we sent them to the Newcomer Center. They went back to their same classroom teachers [upon their return to the mainstream] and everyone noticed a difference. Their language skills had not improved dramatically, but socially they were much more confident (A. Minkin, personal communication, August 4, 1996). 
An interview with the director of the Portland Newcomer Program added additional insight. The director, Sally Anderson, was the author of Project GOAL, the original grant to begin the newcomer program in the Portland district. Ms. Anderson stated, "I believe the program prevents a lot of problems, but how can you prove something that doesn't happen?" (S. Anderson, personal communication, June 7, 1996). In other words, it is impossible to measure social behaviors that did not occur. In addition, we cannot tell if the student would or would not have exhibited specific social behaviors if they had or had not completed the newcomer program. Ms. Anderson also remarked on the difficulties in documentation, the socio-economic differences in the two study groups and the parental input required in Portland for registering students for the newcomer program.

\section{Difficulties in Documentation}

Because many of the students participating in the ESL/Bilingual Program of the Portland Public School District are the children of migrant workers, their family lifestyles require them to move living situations on a frequent basis. For this reason, the children may change schools or even school districts several times a year. Since school records take time to be requested and transferred, it is difficult to document the progress of these students. Several of the students that started in this study moved out of district before questionnaires were handed out to the classroom teachers. The high degree of movement in this population could make any research a challenge. 


\section{Parental Choice}

As discussed in Chapter III, the students from this study came from two different types of programs: mainstream and newcomer. Almost all students who come through the ESL/Bilingual Program's assessment center have the choice of attending the newcomer program or being directly mainstreamed. Ms. Anderson feels that no person knows a child better than the child's parents. Therefore, parents who believe their children do not need to attend a newcomer program are probably correct. If this is true, then the mainstream pre-beginners are possibly starting at a slightly higher ability level than those students who are beginning in the newcomer program. This theory does not always hold true since parents often claim to refuse newcomer service for alternative reasons: belief that the newcomer school is too far away; belief that children should attend the mainstream program as soon as possible; suspicion of government programs. However, the issue of parental choice is still one that could have affected the outcome of the study.

\section{$\underline{\text { Socio-Economic Status }}$}

Students who live on the Southwest side of Portland do not have the option of attending the newcomer program. This is due to the difficulties in bussing mentioned in Chapter III. Interestingly, Southwest Portland is an area of higher rent, higher home prices and therefore higher economic standing than much of the rest of the city. According to Ms. Anderson and the ESL Department, the students from this area are indeed more economically privileged and many come from professional families. This is in contrast to the vast majority of newcomer students who come from low socio- 
economic standing as evidenced by the number receiving free and reduced lunch assistance. This difference in economic privilege could indicate a possible advantage for the students from the mainstream pre-beginner Group B and therefore another possible explanation for the lack of significant difference between the two groups. (S. Anderson, personal communication, June 7, 1996).

It is possible that any or all of these issues could have played a part in the scoring of these two groups. However, the lack of any significant quantifiable difference between groups could indicate that mid-year entry of newly arrived immigrant students is where the true value of newcomer programs is found. Although a child will not, in most cases, enter their mainstream classroom able to "participate at grade level," the newcomer students will enter with survival English skills, as well as a working knowledge of the American school routine and expectations. In this manner it is not unreasonable to expect that newcomer students will enter mainstream classrooms better prepared than their pre-beginner counterparts. Theoretically, this will also save the mainstream teacher several months of individualized basic instruction. As yet another teacher commented:

I am really glad we have Newcomers and help in getting these children off to a good start. It is still very, very difficult when they enter our rooms in all these categories of your project - academic, behavior, rules, etc.

\section{Summary}

The realization that school is often not easy for these children, with or without the newcomer experience, is an important one for classroom teachers to reach. When asked about the particular difficulties they had encountered while working with 
newcomer/pre-beginner students, the teachers mentioned behavioral problems, high numbers of absences, reliance on other native speakers for translation, reluctance to interact with children outside of their first language group, and trouble staying on task. Although the newcomer program is designed to address these issues within the curricula and thereby help students with this transition by introducing them to the common expectations of school and school routine, every school, teacher and classroom is different. The newcomer student must take the knowledge $s /$ he gained from the newcomer program and must adjust it to fit the expectations of the new situation. This adjustment takes some time. As with all students, extenuating circumstances such as personality, family life and academic ability cause ESL and newcomer students' success levels to vary. Given these difficulties in transferring programs, it could be considered meaningful that the newcomer students scored as close to the pre-beginner group as they did. Facing the difficulties of mid-year transition is a difficult challenge for any student. Yet, despite the hurdles of making new friends, learning a new system and adjusting to a new set of teacher expectations, the newcomer students performed as well as the prebeginner group.

\section{DISCUSSION OF UNANTICIPATED RESULTS}

In addition to employing statistical measures in looking at the initial question posed by this study, statistical tests were also used to measure any possible differences in questionnaire responses that may have been a result of gender, language or age differences. Several unanticipated findings resulted. 


\section{Differences According to Gender}

The first of these categories, gender, compared the questionnaire responses that were given for males and females. As reported in Chapter IV, girls scored significantly higher than boys on thirty-nine of the fifty-one questions on the questionnaire. In addition, females also scored significantly higher than the males on each of the four overall general classifications as well. The twelve questions that did not show significant difference are as follows: 13 (Demonstrates progress in English), 14 (Approaching grade level performance), 19 (Tries to participate in all activities), 29 (Mixes with a variety of student groups), 31 (Responds appropriately to others), 32 (Initiates interactions with others), 33 (Forms friendships), 36 (Has made friends outside his/her own language group), 42 (Stays home when ill), 43 (Explains absences due to medical, or other necessities), and 47 (Has satisfactory attendance).

The questions that did show a significant difference between males and females seemed to focus on general social behaviors. Examples of these questions include questions 1 (Pays attention to the instructor), 21 (Refrains from shouting), 37 (Works and plays cooperatively with others), and 41 (Uses drinking fountain appropriately).

Although it is beyond the scope of this paper to explore these unanticipated findings in depth, there are several possible explanations for the discrepancies between males and females.

First, the socialization of boys and girls may be handled differently for each gender. This would indicate that boys and girls may be brought up with a different set of behavioral expectations and therefore behave differently given the same set of 
circumstances. It is interesting to note that if the socialization of boys and girls is different, it would appear to be different to the same degree across cultures - at least the three cultures included in this study. A second possible explanation for the significant findings could be possible differences in the expectations placed upon males and females in the classroom. It would seem plausible, given these findings, that parents, teachers and administrators may hold boys and girls to different standards. And finally, teachers themselves may have biases that lead them to score boys and girls at a different level. Although it was not the original intent of this study to look at the differences between the sexes, the outcomes of the statistical testing did show significant difference between males and females on thirty-nine of the fifty-two questions. More research on this topic would be interesting and relevant to the teaching profession.

\section{Differences Between Age Groups}

A second unanticipated finding of this study included two significant differences by age group. The students in this study were assigned to one of three age groups: first through third grade ( $1-3)$; fourth and fifth grade (4 - 5) and sixth through eighth grade $(6-8)$. Two of the fifty-one questions were statistically significant by age group according to the results from a 1-Way ANOVA and the Kruskal-Wallis measures. The two questions, 19 (Tries to participate in all activities) and 43 (Explains absences due to medical, or other necessities) both conclude that first through third (1 - 3) grade students scored significantly lower than sixth through eighth $(6-8)$ graders with fourth and fifth (4 - 5) graders scoring between the two. In both cases, these differences seem to illustrate the growing confidence, maturity and knowledge base that come to students 
as they get older and gain more experience. This pattern seems to fit in to the current knowledge base on child development. It is beyond the scope of this paper to discuss these findings in detail, but further research in this area could be conducted.

\section{Differences Between Language Groups}

The last area of unanticipated findings was that of language group. Each subject for this study was from one of three language/cultural groups: Spanish, Vietnamese or Russian. Differences between these three groups were measured using the 1-Way ANOVA and the Kruskal-Wallis statistical tests. Significant differences were found in three questions.

The first and second of these, questions 5 (Completes academic tasks to best of personal ability) and 13 (Demonstrates progress in English), showed Russian and Spanish students scoring significantly lower than the Vietnamese students. The opposite result was found in question 36 (Has made friends outside of his/her own language group) in which the Vietnamese students scored significantly lower than the Russian and Spanish students. These results could indicate any or all of a couple of things. The first of these possibilities is that the questionnaire results point to stereotypes held by the classroom teachers. It is possible that some teachers have deeply held beliefs about the strengths and weaknesses of certain cultural groups. These beliefs could have manifested themselves in the outcome of the questionnaire responses. A second possibility is that the cultures themselves could hold different views and expectations toward education. If this is true, it would make sense that these beliefs would express themselves in the behavior and achievement of the children. Finally, the language groups 
could have scored significantly differently from one another because the cultural groups that these languages represent are indeed different. These results seem especially interesting to ESL teachers or others that work with culturally diverse populations since they seem to indicate either a perceived or actual difference between Russian/Spanish speaking students and Vietnamese speaking students. The results would seem to suggest that Russian and Spanish speakers are more culturally similar to each other than to the Vietnamese speakers. These cultural differences also suggest that whereas Russian and Spanish speaking students show strength in social areas, Vietnamese students show strength in academic areas. All of this is, of course, only speculation. Further discussion of this topic is beyond the scope of this paper. However, the study of cultures and cultural beliefs is essential to the teaching of multi-cultural classrooms.

\section{IMPLICATIONS FOR TEACHING}

The results of this study hold several important implications for the teaching of ESL as well as the mainstream teaching of LEP students. These shall be presented below in the same categories as the discussion of results was presented. Newcomers to the United States

The original intent of this study was to determine if any correlation exists between students' completion of the newcomer program and their social and school success in the mainstream. As discussed above, the study did not yield significant results in regard to this question. However, there are still some implications for student placement and teacher training that can be drawn from the data received. 
Although these results do not appear to be conclusive based on the earlier discussion, at this point it seems necessary to tentatively conclude that newly arrived immigrant students can achieve social and school success equally well when starting the year in newcomer as well as mainstream programs. Therefore, it may be to the benefit of students as well as staff to begin as many of these newcomer level students as possible in the mainstream classroom. Therefore, the students do not have to face a mid-year transfer. Alternatively, it would seem equally beneficial to keep students in the newcomer program for an entire year, once again avoiding the stress of mid-year entry. If districts do decide to maintain a direct mainstream placement for newcomer level students, it will be imperative for mainstream as well as ESL teachers to have a clear understanding of not only the language learning process, but also the acculturation process and the special needs for security, comprehensible input and feelings of belonging that newly arrived immigrant children have. Adding more support personnel such as counselors specializing in multi-cultural and acculturation issues could make a notable difference in the newcomer student's acculturation process. In addition, it is important that all teachers and administrators have a realistic understanding of the time requirements for learning a language. Whether a student comes out of a newcomer program or spends his/her first year in a mainstream classroom, s/he will almost never enter the following year at grade level. In addition, the added difficulties of mid-year entry for these students should be considered in advance by teachers and administrators when planning curricula and staffing for the year. 
Implications for Gender Differences

The dramatic number of questions from the questionnaire that showed significantly higher scores for girls than boys illustrates a probable difference in the socialization of these two groups. It then becomes important for educators to develop an awareness of these differences and develop strategies for compensating for the socialized strengths and weaknesses of each group. Teachers and administrators should also try to be mindful of any stereotypes they may hold in this area. If it is true that boys and girls receive such strong societal training, then it is likely that educators have consciously or unconsciously received the training as well. For this reason, teachers should be aware that they may unknowingly hold some of these stereotypes and should therefore be careful that they look at the individual student and not his/her gender.

\section{Implications for Age Differences}

The questions that were found significantly different by age group seem to validate child development theories in that children learn more and are therefore capable of doing more as they age and mature. As with all students the implications of these outcomes seem to be that young ESL students may not be able to achieve the same success that their older brothers and sisters do. However, because children mature in different areas at different rates, it is important to keep in mind that all children are different. Although students mature as they get older, it is still important to consider not only the child's age, but their individual ability levels as well. 
Implications by Language Group

The questions that showed significant difference by language group illustrate the importance of knowledge of cultures. Whether the results from this study indicate actual differences or perceived differences among the cultural groups, the results indicate that knowledge of cultures is important for the avoidance of misunderstanding. Teachers need to be aware that differences in ethnic groups may exist. Different cultures may have diverse expectations of schooling, teachers and the role of students and their families in the educational process. In order to create a better understanding, it may be important for educators to educate themselves on some of the possible value differences among their cultural populations, at the same time being careful not to create negative stereotypes.

\section{Political Implications}

As well as the educational implications outlined above, the results of this study and studies like it hold broader contextual and societal implications as well. Current election year debate and the recent passage of U.S. English in the House of Representatives seem indicative of the current views toward immigration. American citizens seem less and less willing to share their dwindling national resources with new arrivals. National legislation and policy issues such as U.S. English become increasingly more important when federal funding is involved. If a popular move toward U.S. English succeeds, a climate promoting submersion will most likely affect national educational trends. An official national language would possibly take away any support 
for bilingual and transitional bilingual education. Federal funding for such programs could possibly cease to exist.

The underlying views and beliefs toward immigration and immigrants held in this country can have a direct effect on our educational system. Because the implications can be powerful and far reaching, research in these areas is a necessity toward the further development of strong, non-discriminatory and equal education in the United States.

\section{SUGGESTIONS FOR FURTHER RESEARCH}

With an ever growing immigrant population continuing to enter the United States, it is imperative that research continue in the areas of effective teaching methodology and models. Although this study attempted to bring quantitative information into the qualitative discussion of newcomer programs, the results were inconclusive and further research is warranted. The original research question, which sought to discover possible differences in social and school adaptation among newly arrived immigrant students who attended the newcomer program versus those who were directly mainstreamed, showed no significant differences between groups. Future research should attempt a similar study with much larger comparison groups and a more solid research design. As mentioned earlier, it was difficult to design the study in such a way as to allow equal time for both groups in the school system as well as allow them equal standing in the mainstream classroom. Future studies should attempt to solve this timing problem by allotting a longer term design which would span several school years. This would allow the researchers to follow students who enter mid-year as well as those who enter at the beginning of the year. In addition, mid-year entry specifically should be 
looked at as an added piece of the newcomer discussion. Although this study did not look specifically at mid-year mainstream entry for students at this level, it still seems possible to predict that any mid-year entries of newly arrived immigrant students with little to no English would be more successful if placed in the newcomer program rather than the mainstream. This prediction is made on the premise that newcomer programs are designed specifically to support this type of student through smaller class sizes and more specialized lesson plans.

Additional information could have been gathered as well. Future researchers may want to add student interviews to their data base. Interviews conducted during the initial months of school as well as interviews conducted one or two years after the students have entered the district could lead to new insight on the school adjustment process.

Dividing the students by language and socio-economic status would also be helpful in clarifying the data collected in newcomer studies. Previous schooling, parent's education, and socio-economic status all play a potentially large role in the study outcomes.

Although the unanticipated findings of this research project were beyond its scope for detailed analysis, the significant findings do suggest that further research is warranted in the study of roles played by gender, age and language groups in the education of immigrant students as well. For example, future research may want to examine the differences that occurred between the different gender and age groups. Would these differences hold true for native speakers as well as non-native speakers? 
CONCLUSION

Although no significant differences were found in this particular study, this does not definitively imply that the results are conclusive. As discussed earlier, difficulties incurred when conducting this type of educational research as well as flaws in the research design of this specific project, lead to the suggestion that more careful explorations of this topic would be useful. In this particular study, the quantitative data may not show that participation in newcomer programs is any better or worse than the direct mainstreaming of newly arrived students; however, teacher comments and interviews (qualitative data) do in fact point in the newcomer program's favor. Further and more careful research is definitely called for. Evaluations of existing programs and the continuance of experimentation in new ideas and models are imperative if the successful education of all America's children is to be assured. 


\section{REFERENCES}

Alderson, J.C. (1992). Guidelines for the evaluation of language education. In Alderson, J.C., \& Beretta, A. (Eds.), Evaluating second language education (pp. 274- 304). Cambridge: Cambridge University Press.

Associated Press (1996a, June 2). Seattle-area school district learns about "different world." The Oregonian, p. C2.

Associated Press (1996b, July 18). Dole blasts Clinton on school policy. The Oregonian, p. A12.

Baker, K., \& de Kanter, A.A. (1981). Effectiveness of bilingual education: A review of the literature. Washington, D.C.: U.S. Department of Education.

Belluck, P. (1995, March 26). Educators divided on immigrant schools. New York Times, p. N13.

Beretta, A. (1992). Evaluation of language education: An overview. In Alderson, J.C., \& Beretta, A. (Eds.), Evaluating second language education (pp. 5-25). Cambridge: Cambridge University Press.

Bratt Paulston, C. (1980). Bilingual education: Theories and issues. Rowley, MA: Newbury House Publishers, Inc.

California Voter Information (1994). Analysis of Proposition 187 by the legislative analyst. [WWW document]. URL http://ca94.election. digital.com/e/prop/ 187/home.html

Carlson, R.A. (1975). The quest for conformity: Americanization through education. New York, NY: John Wiley and Sons, Inc.

Chamut, A.U. (1983). A transfer curriculum for teaching content-based ESL in the elementary school. (ERIC Document Reproduction Service No. ED 275 146)

Chang, H.N-L. (1990). Newcomer programs: Innovative efforts to meet the educational challenges of immigrant students. San Francisco, CA: California Tomorrow.

Clayton, J.B. (1996). Your land, my land: Children in the process of acculturation. Portsmouth, NH: Heinemann.

Cummins, J. (1988). The role of primary language development in promoting educational success for language minority students. In California State Department of Education Office of Bilingual Bicultural Education, Schooling and language minority students: a theoretical framework. Los Angeles: California State University.

Dinnerstein, L. \& Reimers, D.M. (1988). Ethnic americans. New York: Harper \& Row. 
Dinnerstein, L., Nichols R.L., \& Reimers, D.M. (1990). Natives and strangers: Blacks, Indians, and immigrants in America. New York: Oxford University Press.

Di Rado, A. (1996, August 18). The price of dreams. The Oregonian, p. D1

Evaluation, Dissemination and Assessment Center (1988). Schooling and language minority students. A theoretical framework. Los Angeles, CA: California State University.

Fishman, J. (1966). Language loyalty in the United States. The Hague: Mouton.

Friedlander, M. (1990a). Newcomer centers: A crutch or a ladder? Oakland, CA: Muntifunctional Resource Center/Northern California. (ERIC Document Reproduction Service No. ED 339 230).

Friedlander, M. (1990b). Newcomer education: Programs and issues. Proceedings of the Multifunctional Resource Center/Northern California Symposium. Oakland, CA.

Gersten, R. (1984). The effects of a structured immersion approach to minority language Asian students: Results of a longitudinal evaluation. New Orleans: paper presented at the Annual Meeting of the American Educational Research Association. (ERIC Document Reproduction Service No. ED 247 746)

Gersten, R. (1985). Structured immersion for language minority students: Results of a longitudinal evaluation. Educational Evaluation and Policy Analysis, 7(3), $187-$ 196.

Hakuta, K. (1986). What research evidence says about bilingual education. Paper presented at the Annual Meeting of the National Association for Bilingual Education, Chicago, IL. (ERIC Document Reproduction Service No. ED 270 986)

Hartmann, E.G. (1967). The movement to americanize the immigrant. New York: AMS Press, Inc. (Original work published 1948)

Hernandez, R.E. (1996, August 3). Arguments for English-only law flawed. The Oregonian, p. C6.

Hoffmann, C. (1991). An introduction to bilingualism. New York: Longman.

Hornblower, M. (1995, October 9). Putting tongues in check. Time, pp. 40-50.

Igoa, C. (1995). The inner world of the immigrant child. New York: St. Martin's Press.

Jacobs, J. (1996, March 27). Broken English used to set standards. The Oregonian, p. D7.

Kauper, P.G. \& Beytagh, F.X. (1980). Constitutional Law: cases and materials $\left(5^{\text {th }}\right.$ edition). Boston: Little, Brown \& Company. 
Kennedy, J.F. (1986). A nation of immigrants. New York: Harper \& Row. (Original work published i964)

Krashen, S. (1988). Bilingual education and second language acquisition theory. In California State Department of Education Office of Bilingual Bicultural Education, Schooling and language minority students: A theoretical framework. Los Angeles: California State University.

Krashen, S. (1991). Bilingual education: A focus on current research. Focus, occasional papers in bilingual education, number 3 . Washington, DC: National

Clearinghouse for Bilingual Education. (ERIC Document Reproduction Service No. ED 337 034)

Larsen-Freeman, D. \& Long, M.H. (1991). An introduction to second language acquisition research. New York: Longman Inc.

Lau v. Nichols, 414 U.S. 563 (1974).

Lazerson, M. (1971). Origins of the urban school: Public education in Massachusetts, 1870-1915. Cambridge, MA: Harvard University Press.

McLaughlin, B. (1987). Theories of second-language learning. London: Edward Arnold.

Nunan, D. (1992). Research methods in language learning. Cambridge: Cambridge University Press.

Ochs, E., \& Schieffelin, B.B. (1982). Language acquisition and socialization: Three developmental stories and their implications. Austin, TX: Southwest Educational Development Laboratory. (ERIC Document Reproduction Service No. ED 252 065)

Olsen, L. (1988). Crossing the schoolhouse border. Immigrant students and the California public schools. San Francisco, CA: California Tomorrow.

Olsen, L., \& Dowell, C. (1989). Bridges. Promising Programs for the education of immigrant children. San Francisco, CA: California Tomorrow. (ERIC Document Reproduction Service No. ED 314 544)

Portland Public Schools ESL/Bilingual Program. (1995). Lau Compliance Plan. Portland, OR: Author.

Portland Public Schools ESL/Bilingual Program. (1990). Project GOAL: General orientation, assessment and literacy: A Title VII transitional bilingual education project fourth year report. Portland, OR: Author. 
Portland Public Schools ESL/Bilingual Program. (1987). Project GOAL: Elementary newcomer school orientation curriculum. Portland, OR: Author.

Reimers, D.M. (1985). Still the golden door: The third world comes to America. New York: Columbia University Press.

Rossell, C.H. (1988). The problem with bilingual research: A critique of the Walsh \& Carballo study of bilingual education projects. Equity \& Excellence, 23(4), 2529.

Snow, C.E. (1988). The problem with bilingual education research critiques: A response to Rossell. Equity \& Excellence, 23(4), 30-31.

Tyack, D.B. (1974). The one best system: A history of American urban education. Cambridge, MA: Harvard University Press.

U.S. Bureau of the Census (1995). Statistical abstract of the United States: 1995. (115 Edition). Washington, DC: Author.

U.S. Bureau of the Census (1975). Historical statistics of the U.S., colonial times to 1970 (Part I). Washington, DC: Author.

Walling, D.R. (1993). English as a second language: 25 questions and answers. Bloomington, IN: Phi Delta Kappa. (ERIC Document Reproduction Service No. ED 356653 )

Walsh, C., \& Carballo, E. (1986). Transitional bilingual education in Massachusetts: A preliminary study of its effectiveness. Boston, MA: Bridgewater State College. (ERIC Document Reproduction Service No. ED 270 990)

Walsh, C.E. (1988). Doing bilingual research in schools: A response to Christine H. Rossell. Equity and Excellence, 23(4), 32-35.

Willig, A. (1985). A meta-analylsis of selected studies on the effectiveness of bilingual education. Review of Educational Research, 55, 269-317.

Witt, E. (1990). Guide to the US Supreme Court ( $2^{\text {nd }}$ edition). Washington, DC: Congressional Quarterly.

Wong Fillmore, L. (1991). When learning a second language means losing the first. Early Childhood Research Quarterly, 6(3), 323-347.

Wong Fillmore, L. (1986). Research currents: Equity or excellence? Language Arts, 63(5), 474-481. 
Wong Fillmore, L. (1985). Second language learning in children: A proposed model. Arlington, VA: Proceedings of a Conference on Issues in English Language Development for Minority Language Education. (ERIC Document Reproduction Service No. ED 273 149) 
APPENDIX A

SUMMARY OF ESL/BILINGUAL

PROGRAM MODELS 
TYPES OF ESL/BILINGUAL MODELS

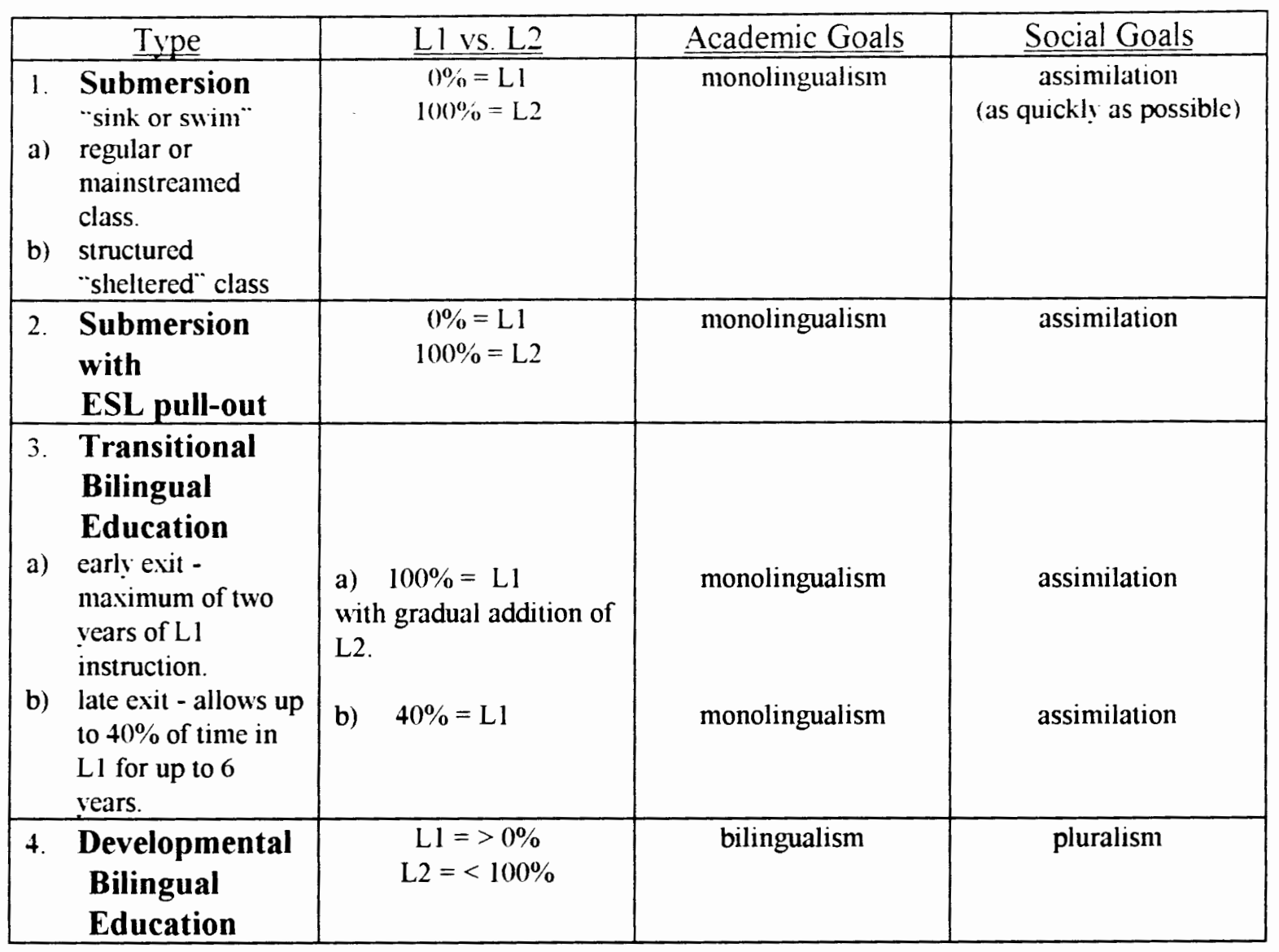




\section{APPENDIX B}

IDENTIFICATION AND PLACEMENT OF ESL STUDENTS

IN THE PORTLAND PUBLIC SCHOOL SYSTEM 


\section{IDENTIFICATION \\ and \\ PLACEMENT of STUDENTS}

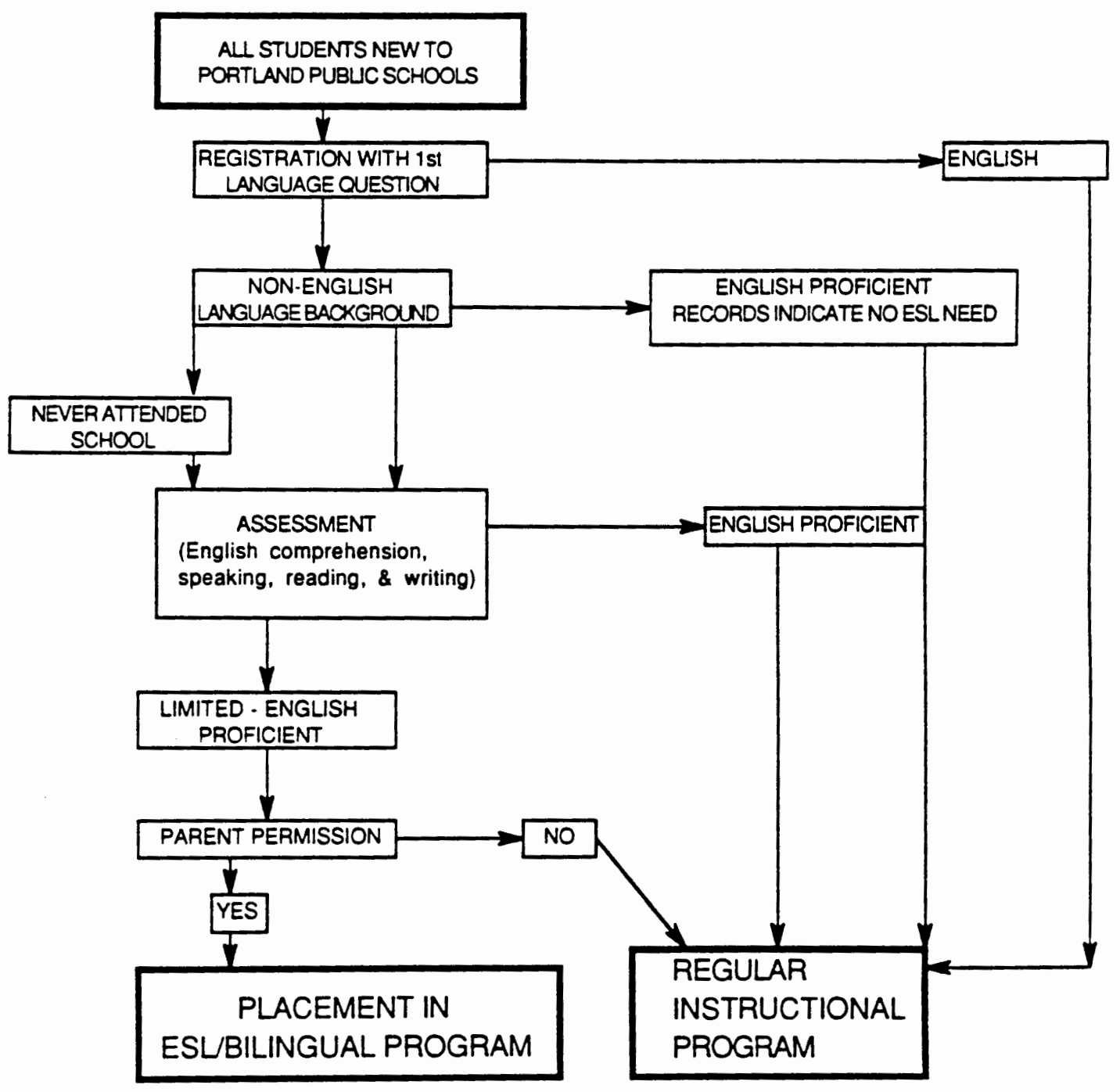


APPENDIX C

DEMOGRAPHIC BREAKDOWN OF STUDY PARTICIPANTS 


\begin{tabular}{|c|c|c|c|c|c|c|c|c|}
\hline \multicolumn{8}{|c|}{ Demographic Breakdown - Newcomer Group A } \\
\hline & Spanish & \multicolumn{2}{|c|}{ Vietnamese } & \multicolumn{2}{c|}{ Russian } & \multicolumn{2}{|c|}{ Total } \\
\hline & Males & Females & Males & Females & Males & Females & Males & Females \\
\hline 1-3 Grade & 4 & 1 & 2 & 3 & 1 & 1 & 7 & 5 \\
\hline 4-5 Grade & 2 & 4 & 2 & 1 & 0 & 1 & 4 & 6 \\
\hline 6-8 Grade & 3 & 0 & 2 & 2 & 2 & 0 & 7 & 2 \\
\hline Total & 9 & 5 & 6 & 6 & 3 & 2 & 18 & 13 \\
\hline
\end{tabular}

\begin{tabular}{|c|c|c|c|c|c|c|c|c|}
\hline \multicolumn{6}{|c|}{ Demographic Breakdown - Pre-Beginner Group B } \\
\hline & Spanish & \multicolumn{2}{|c|}{ Vietnamese } & \multicolumn{2}{|c|}{ Russian } & \multicolumn{2}{|c|}{ Total } \\
\hline & Males & Females & Males & Females & Males & Females & Males & Females \\
\hline 1-3 Grade & 0 & 1 & 1 & 1 & 6 & 3 & 7 & 5 \\
\hline 4-5 Grade & 2 & 2 & 0 & 0 & 1 & 1 & 3 & 3 \\
\hline 6-8 Grade & 0 & 1 & 4 & 0 & 0 & 0 & 4 & 1 \\
\hline Total & 2 & 4 & 5 & 1 & 7 & 4 & 14 & 9 \\
\hline
\end{tabular}

\begin{tabular}{|c|c|c|c|c|c|c|c|c|}
\hline \multicolumn{8}{|c|}{ Demographic Breakdowns - Whole Sample } \\
\hline & Spanish & \multicolumn{2}{|c|}{ Vietnamese } & \multicolumn{2}{|c|}{ Russian } & \multicolumn{2}{|c|}{ Total } \\
\hline & Males & Females & Males & Females & Males & Females & Males & Females \\
\hline 1-3 Grade & 4 & 2 & 3 & 4 & 7 & 4 & 14 & 10 \\
\hline 4-5 Grade & 4 & 6 & 2 & 1 & 1 & 2 & 7 & 9 \\
\hline 6-8 Grade & 3 & 1 & 6 & 2 & 2 & 0 & 11 & 3 \\
\hline Total & 11 & 9 & 11 & 7 & 10 & 6 & 32 & 22 \\
\hline
\end{tabular}




\section{APPENDIX D}

CONSENT FORMS 
¿NFORMEJ CENSENT FORM

$\therefore$,

the effectiveness of the Newcomer Program or the schosl sajustment of jmmigrant

enildren.

I understand that the study involves filling out a questionnajre about E.S...

students in my class, as well as classroom cbservations by the researcher.

I understand that because of the study, I will have the researeher visit my

classroom on several occasions during the $1994-95$ school year. I may also be asked to

c osely observe the research subjects in my classroom in order to complete the study

questionnaire.

Beth Essex has told me that the purpose of the study is to learn the best methods for helping newly arrived immigrant students adjust to the American school system.

I may not receive any direct benefit from taking part in this study. But the

study may help to increase knowledge that may help others in the future.

Beth Essex has offered to answer any questions I have about the study and what I am expected to do.

She has promised that all information I give will be kept confidential, and that

the names of all people in the study will remain anonymous.

I understand that I do not have to take part in this study, and that this will not affect my relationship with the Portland Public School System.

I have read and understand the above information and agree to take part in this stuov.

Date:

Signature:

If you have any concerns or questions about this study, please contact the Chair of the Human Subjects Research Review Committee, Office of Research and Sponsored Projects. 105 Neuberger Mall, Portlano State University, 503/725-3417. Or, call the researche-, Betn Essex, at 503/239-0787. 


\section{ĐƠN CHO PHÉP}

Tôi đồng ý cho con tôi tên là

được tham gia vào CHƯƠNG TRİNH NGHIÊN CỮU. Phương án này sẽ nghiên cứu hiệu quá của chương trình dành cho những em mới đến định cư (Newcomer Program) về sự diều chính khá năng thích hợp với khung trường mới.

Tôi hiểu rằng vị nghiên cưu viên sẽ quan sát con tôi trong lợp học và cũng sẽ xem xét hồ sơ học vấn của con tôi.

Vị nghiên cứu viên tên là ELIZABETH ESSEX. Cô ELIZABETH đă cho tôi biết lý do của việc học hơi này là cách giúp đớ tồt nhất cho các em học sinh được ốn định ớ trường hoc Hoa Kỳ.

Tôi cūng hiểu rằng con tôi và tôi có thể không thâu thập được khoáng lợi ích nào khi tham gia chương trình này, nhưng sự học hơi này cơ thể giưp ích cho việc học vấn trong tương lai.

CO EL IZABETH sẽ trá lởi bất cứ ván đề nào mà tôi quan tâm trong chương trình này.

Danh tánh và tin tức liên quan về con tôi sẽ được giưu kín và không được sữ dụng.

Con tôi không buột phải tham gia vào chương trình này, và sự quyết định này sẽ không ánh hưỡng đến khóa học của con tôi.

Tơi đă đọc và hiểu qua những tin tức nêu trên, tôi đồng ý cho con tở tham gia vào ván đề nghiên cứu này.

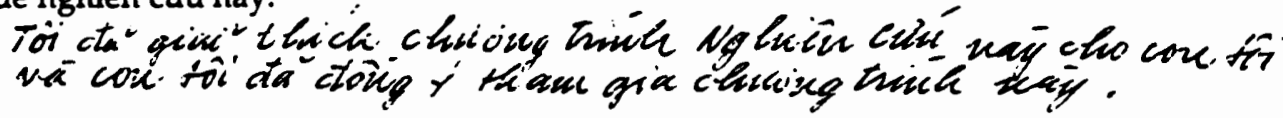

Ký tên Ngày

Hue $\sinh x y$ iten Ngáng

Nếu Phu Huynh có câu hơi gì vè CHƯONG TRINH NGHIEN CỨU này, xin vui lơng liên lạc với cơ quan The Chair of the Human Subjects Research Review Committee, Office of Research and Sponsored Projects, 105 Newberger, Portland University, 503/725-3417 - hoac co Elizabeth Essex, 503/239-0787. 


\section{FORMA DE CONSENTIMIENTO INFORMADO}

Yo le doy permiso a mi hijo-a

(nombre del padre o madre)

para que participe en este proyecto de estudio. Este proyecto estudiará cuan efectivo es el programa de Recien Llegados en la adquicisión de conocimientos 0 abilidades de los niños immigrantes en la escuela.

Entiendo que mi hijo-a sera observado en clase por la maestra encargada. La maestra encargada se llama Elizabeth Essex. Miss. Essex ha dicho que la razón para hacer el estudio es aprender los mejores métodos para ayudar a los estudiantes recien llegados para adaptarse a la escuela americana.

Entiendo que mi hijo-a y yo no recibiremos ningun beneficio personal por participar en este estudio, pero que este estudio puede ser de gran beneficio para el futuro de la educación de aquellos estudiantes recien llegados a los Estados Unidos.

Miss. Essex contestará cualquier pregunta que Ud. le haga sobre el estudio. Toda información sobre mi hijo-a sera confidencial y su nombre no sera usado.

Mi hijo-a no tiene que participar en este estudio, y esta decisión no afectará en nada el transcurso de su año escolar.

He leido la información de arriba y estoy de acuerdo en que mi hijo-a tome parte en este estudio.

Le he explicado este estudio a mi alumno y el/ella está de acuerdo en participar.

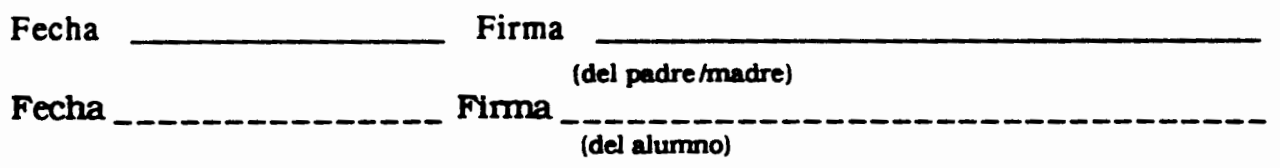

Si tiene alguna pregunta sobre este estudio, por favor Dame a Chair of the Human Subjects Research Review Committee. Office of Research and Sponsored Projects, 105 Neuberger Hall. Portland State University. 503/725-3417. Para hablar con Elizabeth Essex lame al 503/239. 0787. 


\section{Информация о разрешении.}

Я,

участвовать в этом исследовании. Это

исследование будет изучать зффективность программы для

новоприбывших детей иммигрантов и изучать их улучшение в знаниях.

Я понимаю, что мой ребёнок будет под наблюдением

исследователя в классе, так же исследователь будет смотреть школьное дело моего ребёнка.

Имя исследователя Элизабет Эсекс (Elizabeth Essex). Она мне сказала, что причина для этого исследования - найти лучший путь помощи новым детям иммигрантам привыкнуть к американской школе.

Я понимаю, что я и мой ребёнок не получат за это исследование никакой персональной помоши, но это исследование будет полезным для будещего образования.

Элизабет Эсекс ответит на любые вопросы, интересуюшие меня по поводу этого исследования. Вся информация о моём ребёнке является частной и оглашению не подлежит и его (её) имя не будет использовано.

Мой ребёнок не обязательно должен участвовать в этом исследовании. Это решение не окажет никакого влияния на его (её) оценку.

Я прочитал и понимаю информашию данную выше и согласен дать моему ребёнку участвовать в этом исследовании.

Я объяснил своему ребёнку об этом исследовании и мой ребёнок согласился учавствовать в нём.

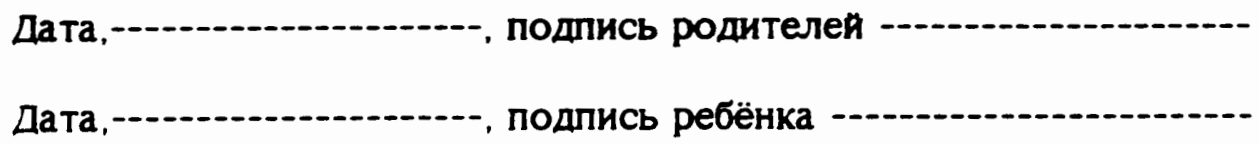

Если у вас есть вопросы Об этом исследовании, звоните или пишите. Chair of the Human Subject Research Review Committee, Office of Research and Sponsored Projects, 105 Neuberg Hall, Portland State University, 503/725-3417. Нли звоните к исследователю Элизабет Эсекс (Elizabeth Essex) 503/239. 0787. 
APPENDIX E

QUESTIONNAIRE 


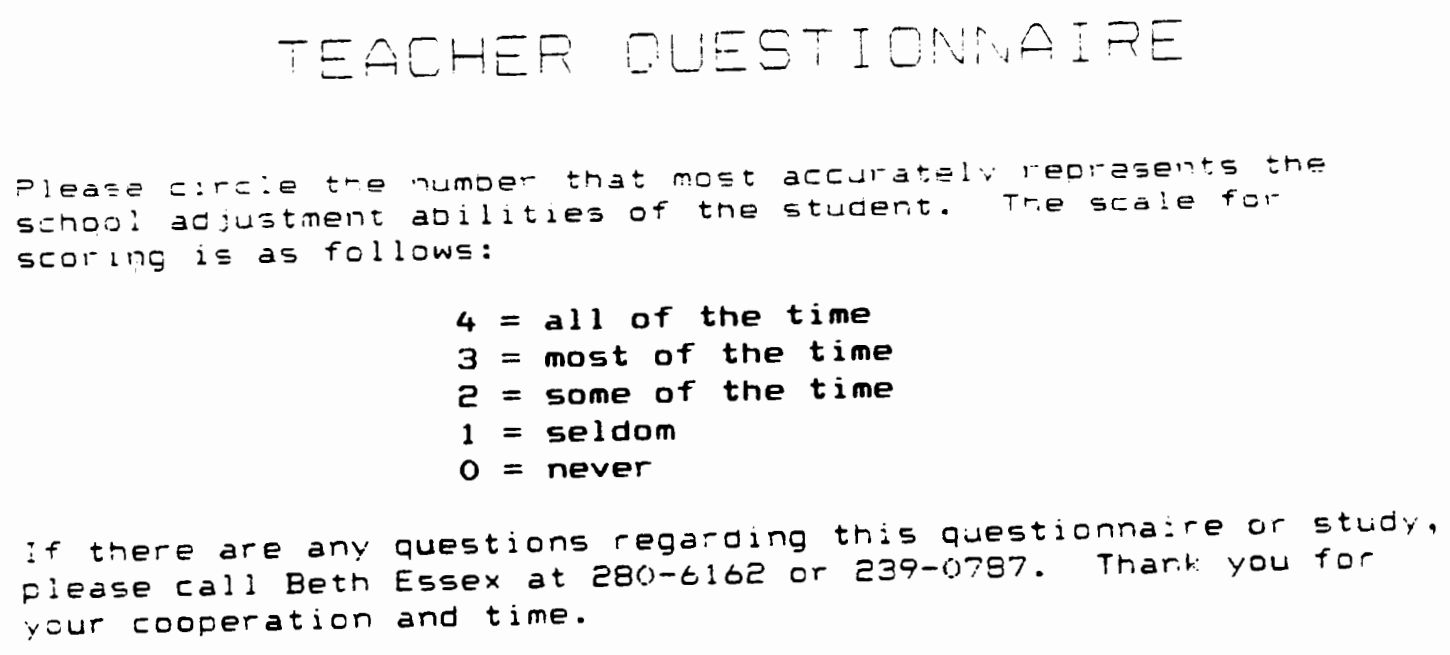

\section{ACADEMIC}

1. Pays attention to the instructor

01234

2. Exhibits appropriate behavior during various instructional activities

3. Focuses on instructional activities

01234

4. Demonstrates interest in learning

5. Completes academic tasks to best of personal ability

01234

6. Follows directions

7. Adheres to sehool rules

8. Demonstrates understanding of time

8. (class/bus schedules, avoids being tardy) 01234

9. Is responsible for classrcom materials 01234 $\begin{array}{ll}\text { 10. Treats instructional equipment and } & 01234 \\ \text { materials respectfully } & \end{array}$

11. Shares instructional materials

12. Responds appropriately to non-instructional school personnel

13. Demonstrates progress in English

14. Approaching grade level performance 


\section{BEHAVICR}

15. Refrains from fighting

01234

16. Respects personal anc property rights of others

$0: \equiv 34$

17. Refrains from inappropriate touching of otners

$01 \geq 34$

18. Awaits turn to speak or act

01234

19. Tries to participate in all activities

$01 \geq 34$

20. Refrains from aisruption of class or class activities

01234

21. Refrains from shouting

01234

22. Does not erowd in line

01234

23. Does not make inappropriate gestures

01234

24. Does not use offensive language

01234

25. Does not require constant monitoring

01234

26. Demonstrates safe behavior on school bus

01234

27. Demonstrates appropriate playground behavior

01234

28. Demonstrates appropriate behavior for nallways

01234

COMMENTS (please use back of paper if needed):

INTERPERSONAL RELATIONS
29. Mixes with a variety of student groups
0 i 234
30. Is neither a victim nor an aggressor
01234
31. Responds appropriately to others
01234
32. Initiates interactions with others
01234 


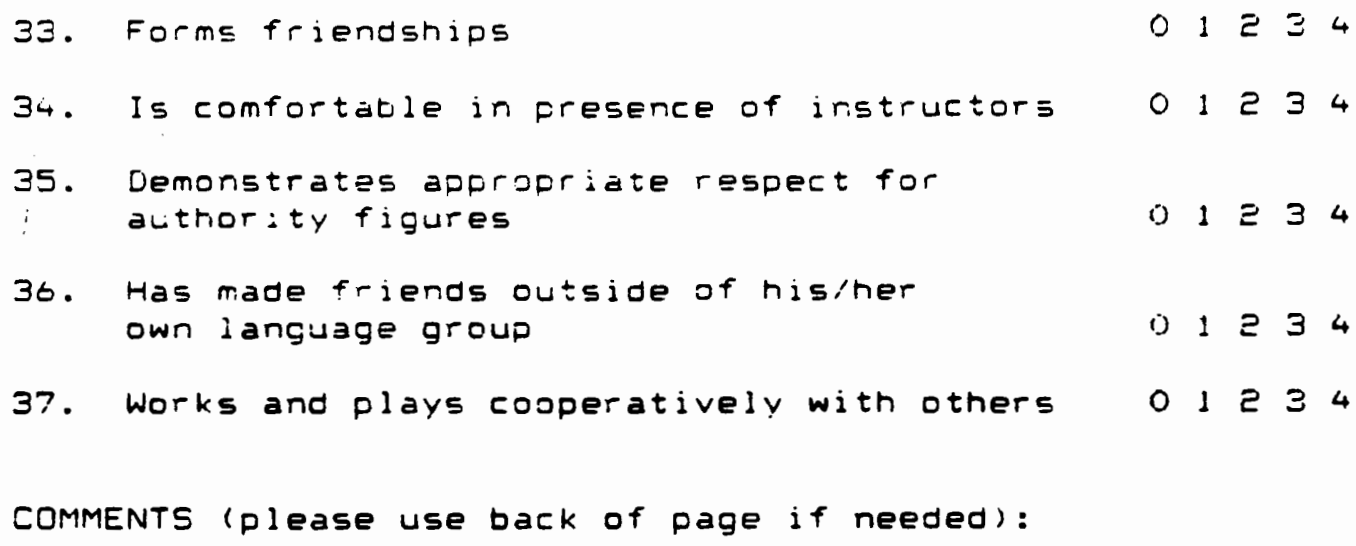

KNOWLEDGE OF SCHOOL ROUTINE/RULES

38. Follows classroom rules

01234

39. Dresses appropriately for the weather

01234

40. Demonstrates appropriate use of rest room facilities

01234

41. Uses drinking fountain appropriately

01234

42. Stays home when ill

01234

43. Explains absences due to medical, or other necessities

01234

44. Demonstrates appropriate behavior during fire drills

45. Demonstrates appropriate behavior during earthquake orills

46. Demonstrates appropriate behavior for assemblies

47. Has satisfactory attendance

01234

48. Demonstrates appropriate benavior in the cafeteria

49. Follows procedures for attaining luneh tickets 


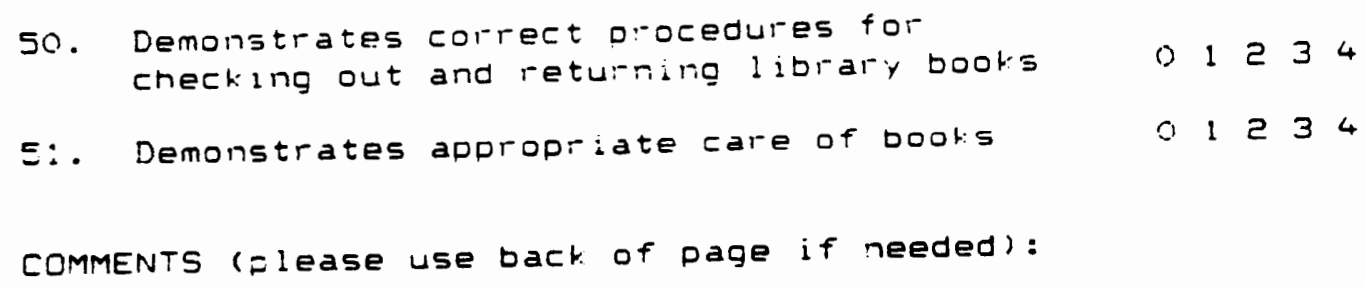

\section{ADDITIONAL INFORMATION}

Student's entry date into your classroom:

Number of hours per day student receives ESL instruction:-_- - -

Please comment on any special measures you may have taken for this child in the classroom (buddies, special worksheets, seating, ete.):

Please comment on any difficulties you may or may not have encountered in including this child into the daily classroom routine:

Please comment on your knowledge of the Portland Public Schools Newcomer Program: 
APPENDIX F

PRE- AND POST PROGRAM EVALUATIONS USED BY PROJECT GOAL

PROJECT GOAL OBJECTIVES 
PROJECI Go' NEWCOMER

SCHOOL ORIEMTATIOM PRE-POST EVALUATION

Student Mame

Evaluator

\begin{tabular}{|c|c|c|c|}
\hline SKILL AREAS TESIED & EVALUATION PROCEDURE & PRE & POSI \\
\hline $\begin{array}{l}\text { Mork Habits/Social Skills } \\
\text { A. L istens and follows directions. }\end{array}$ & $\begin{array}{l}\text { Pre-Post Observation } \\
\text { A. Watch student to see if he/she istens and } \\
\text { follows instructions in class. }\end{array}$ & & \\
\hline E. Participates in classroom activitles & $\begin{array}{l}\text { E. Watch to see if student participates in } \\
\text { classroum activities. }\end{array}$ & & \\
\hline f. Iresses appropriately for weather & $\begin{array}{l}\text { F. Observe dress of student. Is it appropriate } \\
\text { for the meather? }\end{array}$ & & \\
\hline $\begin{array}{l}\text { Basic School Information } \\
\text { A. Names school }\end{array}$ & $\begin{array}{l}\text { Pre-Post Quest ion/Answer } \\
\text { A. Instructor: "What Is the name of inis school?" } \\
\text { Student: Responds with correct name of scliool-- } \\
\text { Vestal }\end{array}$ & & \\
\hline $\begin{array}{l}\text { D. Locates, names and identifies rooms in the } \\
\text { school. } \\
\text { 1. Restroom }\end{array}$ & $\begin{array}{l}\text { D. Instructor: "Show me where the restron is?" } \\
\text { Student: Responds by tak ing the structor to } \\
\text { the restroom and namili, . l. }\end{array}$ & & \\
\hline $\begin{array}{l}\text { School Procedures and Rules } \\
\text { F. Demonstrates correct behavior in hall ways. } \\
1 \text {. Malks in hallway }\end{array}$ & $\begin{array}{l}\text { Pre-Post Observation } \\
\text { F. Observe student walking in hallway, not running. } \\
\text { skipping, etc. }\end{array}$ & & \\
\hline $\begin{array}{l}\text { K. Demonstrates knowledye of classroom rules. } \\
\text { 1. No gum chewing or eat ing candy ill school. }\end{array}$ & $\begin{array}{l}\text { K. Observe whether student complies with the } \\
\text { classroom rule of no gum chewing or eat ing candy }\end{array}$ & & \\
\hline $\begin{array}{l}\text { P.F. Program and Playground Rules } \\
\text { A. Demonstrates knowledge of and complies with } \\
\text { free play rules. } \\
\text { 1. Forms order iy line as requested by } \\
\text { instructor to leave playground. }\end{array}$ & $\begin{array}{l}\text { A. Observe whether student refrains from pushing. } \\
\text { shoving, or kicking. }\end{array}$ & & \\
\hline $\begin{array}{l}\text { School lunch Program } \\
\text { A. Follows procedures for lunch line. } \\
\text { 1. Keep hands to self. }\end{array}$ & $\begin{array}{l}\text { A. Observe student behavior in Iine for keeping } \\
\text { hands to self. }\end{array}$ & & \\
\hline 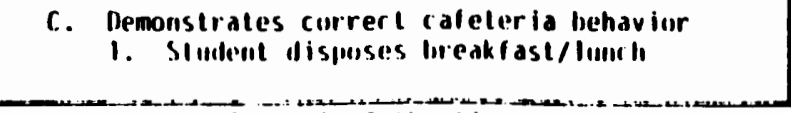 & $\begin{array}{l}\text { C. Observe thether student disposes of breakfast/ } \\
\text { lunch remains by putt ing thew in the des ignited } \\
\text { area/containers. }\end{array}$ & & \\
\hline
\end{tabular}




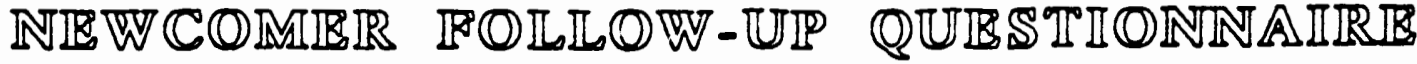

Teacher Name

Date

Student Name

Grade

Project \#

Please rate students individually on a scale from 1 to 5 , with 1 being the least, weakest or infrequent, and 5 being the most, strongest or most frequent.

\section{ACADEMIC}

1. Demonstrates progress in Enghish

Seale

2. Approsching grade level performance

Comments:

\section{BEHAVIOR}

1. Demonstrates appropriate classroom behavior

Comments:

\section{ATTENDANCE}

1. Has satisfactory attendance

Comments:

\section{GRADEPLACEMENT}

1. Has this student been retained?

Comments:

\section{PEER RELATIONS}

1. Gets along well with others

2. Has made friends outside his/her own language group

\section{Comments:}


SCHOOL ACTIVITIES

1. Involved in constructive, non-academic activities-(band, chorus, sports, clubs)

Yes No

2. Which special classes, if any, is student involved? (TAG, Special Ed., etc.)

Comments:

\section{SPECLAL NEEDS}

1. Are there special family problems?

2. Are there special medical problems?

Yes No

Yes No

Comments:

\section{PARENTSINVOLVEMENT}

1. Have there been any home visits?

2. Have parents attended parent-teacher conference open hourse or other school activities?

Comments:

Please write in results for this student

IDA

PALT

GST

\section{WRITING SAMPLE: (Please attach)}

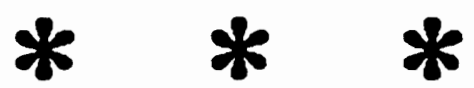

Pleasereturnby PONY: Sally Anderson

Projeet GOAL / Newcomer

Vestal School 


\section{NEWCOMERS' PROGRAM}

THE CLIENTS TO BE SERVED

Project goal has been designed to serve three categories of clients. The categories include students, parents of participants and staff members who serve the students.

Students

The Project focuses on newly arrived; non-English speaking students in grades three through eight. Specifically, the Project has been designed for students whose English language proficiency places them into beginning English category or whose literacy level within the native language is minimal. (The operable criteria for selecting students into the Project have been detailed within the following exhibit.) The students receive English language instructi on, native language literacy, math, and orientation to the American school setting.

During the initial year of the Project, it is anticipated that approximately 100 students will participate in the Project. Based upon current enrollment projections, it is expected that the majority of Project participants will be newly arrived Southeast Asian or Hispanic.<smiles>[C]1[CH]C1</smiles> 
APPENDIX G

NEWCOMER PROGRAM EXIT CRITERIA 
Name:

Date:

1. Concensus of opintion of the GOAL/Newcomer staff: "This student is "ready' for exit." (Staff observation/judgment)

2. Student in grades $6-8$ scored at least 18 points in Level 111 of the GOAL/ESL test.

3. Student in grades $3-5$ scored at least 18 points in Level II of the GOAL/ESL test.

4. Student has been exposed to the orfentation curriculum and demonstrated understanding of bastc school rules and expectations.

5. Student has improved native language literacy skills.

6. Student feels okay about/ready for being exited according to conference with bilingual and/or ESL teacher.

7. Extended assessment concerns have been addressed: age/grade placement; health problens; involvement of Child Study Team; etc.

8. Parent is in agreement about extt.

9. Length of service: student has been with 60AL/Newcomer three to six months. (Consider maximum amount of time for middle school students and student's prelfterate/nonifterate background.)

10. Student wath skills are within three years of grade level in math sktlis for grade 6-8.

11. Student math skills are within two years of grade level in math skt11s for. grades 3-5.

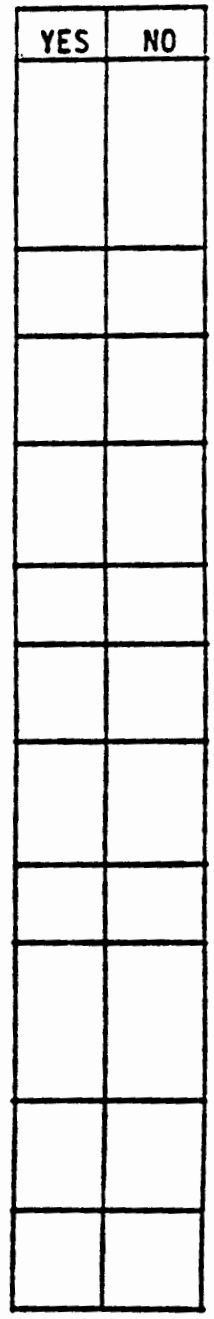

12. Other considerations; strengths to consider: 